The research program of the Center for Economic Studies (CES) produces a wide range of theoretical and empirical economic analyses that serve to improve the statistical programs of the U.S. Bureau of the Census. Many of these analyses take the form of CES research papers. The papers are intended to make the results of CES research available to economists and other interested parties in order to encourage discussion and obtain suggestions for revision before publication. The papers are unofficial and have not undergone the review accorded official Census Bureau publications. The opinions and conclusions expressed in the papers are those of the authors and do not necessarily represent those of the U.S. Bureau of the Census. Republication in whole or part must be cleared with the authors.

\title{
SPATIAL MISMATCH OR RACIAL MISMATCH?
}

\author{
by
}

Judith K. Hellerstein *

University of Maryland and NBER

\author{
David Neumark * \\ UCI and NBER
}

and

Melissa McInerney*

U.S. Bureau of the Census and University of Maryland

CES 07-16 June, 2007

All papers are screened to ensure that they do not disclose confidential information. Persons who wish to obtain a copy of the paper, submit comments about the paper, or obtain general information about the series should contact Sang V. Nguyen, Editor, Discussion Papers, Center for Economic Studies, Bureau of the Census, 4600 Silver Hill Road, 2K132F, Washington, DC 20233, (301-763-1882) or INTERNET address sang.v.nquyen@census.gov. 


\begin{abstract}
We contrast the spatial mismatch hypothesis with what we term the racial mismatch hypothesis - that the problem is not a lack of jobs, per se, where blacks live, but a lack of jobs into which blacks are hired, whether because of discrimination or labor market networks in which race matters. We first report new evidence on the spatial mismatch hypothesis, using data from Census Long-Form respondents. We construct direct measures of the presence of jobs in detailed geographic areas, and find that these job density measures are related to employment of black male residents in ways that would be predicted by the spatial mismatch hypothesis - in particular that spatial mismatch is primarily an issue for low-skilled black male workers. We then look at racial mismatch, by estimating the effects of job density measures that are disaggregated by race. We find that it is primarily black job density that influences black male employment, whereas white job density has little if any influence on their employment. This evidence implies that space alone plays a relatively minor role in low black male employment rates.
\end{abstract}

* This research was supported by the Russell Sage Foundation and NICHD grant R01HD042806. Hellerstein and Neumark are research associates of the NBER. Neumark is also a research fellow at IZA. We are grateful to Joel Elvery and Melinda Sandler for outstanding research assistance, and to Chris Jepsen, Jed Kolko, Lorien Rice, Dan Weinberg, and seminar participants at the University of Chicago for helpful comments. This paper reports the results of research and analysis undertaken while the first two authors were research affiliates at the Center for Economic Studies at the U.S. Census Bureau. It has undergone a Census Bureau review more limited in scope than that given to official Census Bureau publications. It has been screened to ensure that no confidential information is revealed. Research results and conclusions expressed are those of the authors and do not necessarily indicate concurrence by the Census Bureau or the Russell Sage Foundation. 
"To find a job is like a haystack needle

Cause where he lives they don’t use colored people”

Stevie Wonder, Living for the City (1973)

\section{$\underline{\text { I. Introduction }}$}

A concise statement of the spatial mismatch hypothesis is that "there are fewer jobs per worker in or near black areas than white areas” (Ihlanfeldt and Sjoquist, 1998, p. 851), and that this holds down black employment prospects. The alternative we consider in this paper is that race matters more explicitly, and that the problem is not so much a lack of jobs in areas where blacks reside, but a lack of jobs in those areas that employ blacks. In either case, for blacks finding a job may be “like a haystack needle.” But whereas the spatial mismatch hypothesis attributes this to a lack of jobs per se, the "racial mismatch" hypothesis suggests that this has more to do with whether blacks are able to get the available jobs.

The spatial mismatch hypothesis typically is viewed as most salient to less-skilled individuals who face higher mobility costs relative to earnings, and has therefore been characterized often as most relevant to lower-skilled, inner-city blacks. In this paper we take advantage of highly detailed Census data on both residential and employer location to assemble new evidence on spatial mismatch. In particular, we look at highly disaggregated geographic areas of residence, and estimate the relationship between job

density in these areas and employment. Because the spatial mismatch hypothesis is most likely to apply to less-skilled individuals, we condition on an individual's education and consider job density measures defined by education in order to isolate results for less-skilled individuals. This new analysis, which generates evidence consistent with spatial mismatch for less-skilled individuals, is one contribution of our paper. The more substantive contribution, however, is to explore whether the evidence is really generated by spatial mismatch, or instead reflects what we refer to as racial mismatch.

The pure spatial mismatch hypothesis implies that it is only the location of jobs, irrespective of whether they are held by blacks or whites, which affects employment prospects. In contrast, if discrimination or labor market networks in which race matters play important roles, the availability of jobs held by members of one's own race may be the more relevant determinant of employment status. 
Given patterns of residential segregation, and given that urban areas with large concentrations of black residents may also be areas into which whites tend to commute in order to work, it is possible that the employment problems of low-skilled inner-city blacks may not reflect simply an absence of jobs where they live, even at appropriate skill levels, but rather that the jobs that do exist tend to be held by whites. This motivates our inquiry into whether the spatial distribution of jobs across areas where blacks live, or the racial composition of those jobs - conditional on skill - is a more important determinant of their employment. Note that in the latter case the spatial distribution of jobs is still important, but it is the spatial distribution of jobs held by blacks that is central.

Spatial mismatch is premised on the existence of residential segregation by race, of which there is strong evidence (e.g., Massey and Denton, 1987; Cutler, et al., 1997), and which is assumed to create some exogenous variation in where people - especially blacks - live. Spatial mismatch leads to worse employment prospects for blacks in racially segregated areas. As a result, the net wage (defined as the wage minus commuting costs) earned by a worker who lives in a black area and works at a job far away may be below a worker's reservation wage, so that fewer residents of black areas will choose to work. This will be more true of lower-skilled blacks, for whom commuting costs represent a larger share of earnings. It may also be accentuated by worse public transportation options from inner-city areas to suburban work sites, which again will more severely impact lower-skilled individuals who rely on public transportation. The spatial mismatch hypothesis posits that via these channels residential segregation leads to overall lower employment rates among blacks. This may be reinforced by an excess supply of workers to firms near heavily black residential areas, causing the wages of workers living in those areas to fall and further reducing incentives for employment.

Among the factors typically discussed in the spatial mismatch literature as contributing to the persistence of these black-white employment differentials are the continuing movement of jobs out of central city areas, discrimination in housing that prevents mobility of blacks to where jobs are located, and other factors such as customer discrimination against blacks (which might also reduce black employment prospects in white areas) and poor information about jobs in other areas (Ihlanfeldt and 
Sjoquist, 1998). The existence of spatial mismatch can also generate empirical evidence that is indistinguishable from that generated by models of "neighborhood” or "peer effects," where labor market behavior and outcomes of an individual are partially determined by the behavior of people with whom an individual interacts in a non-work setting, based largely on residential location (see, e.g., Case and Katz, 1991; Borjas, 1995; Aaronson, 1998; and Evans, et al. 1992). ${ }^{1}$

The spatial mismatch hypothesis primarily concerns decisions of workers to supply labor given their reservation wages. In contrast, models of discrimination emphasize lower labor demand for blacks that causes them to earn less than whites and to face worse employment prospects (e.g., Becker, 1971; Bergmann, 1974). There is ample evidence that blacks (and other minorities) disproportionately work in lower-paid occupations and firms. For example, in previous work (Bayard, et al., 1999), we show that workplace segregation of blacks from whites is an important contributor to racial wage gaps for both men and women. ${ }^{2}$ If discrimination is an important determinant of labor demand for blacks and whites, then even if jobs are plentiful in a particular area, employment prospects for blacks may not be strong if employers in these areas do not tend to hire blacks. In this case, it is the availability of jobs for blacks in an area, rather than overall availability, that will play a stronger role in determining black employment.

This implication of discrimination is no different from what would be implied by an important role for informal labor market networks that are stratified to some extent by race. Granovetter (1974) is one of the early sources of evidence on the importance of informal contacts in finding employment. He also discusses the potentially important role of informal contacts with members of one's own race, and how a "multiplier" effect for a particular racial group can be generated from increased employment of that group. ${ }^{3}$ Distinguishing between discrimination and network effects is beyond the scope of this paper.

\footnotetext{
${ }^{1}$ These neighborhood effects may arise through a variety of mechanisms, including a lack of role models, the absence of informal networks to help in finding good jobs, or externalities in the consumption of leisure (with leisure valued more highly when others in the neighborhood are also spending large quantities of time in non-work activities). But these effects are difficult to distinguish from the effects of the spatial distribution of jobs.

${ }^{2}$ There is also direct evidence of at least some discriminatory barriers to hiring, such as those that have been highlighted by audit or correspondence studies (Turner, et al., 1991; Bertrand and Mullainathan, 2004).

${ }^{3}$ Holzer and Neumark (2000) provide some evidence on the importance of networks in employment. They show that hiring under Affirmative Action is associated with increased use of private agencies and newspapers in
} 
Instead, we only examine whether it is the spatial distribution of jobs that disadvantages less-skilled blacks or instead whether it is also the racial composition of jobs in that area - whether because of discrimination or networks. That is, the problem may not be simply that blacks are spatially mismatched with respect to jobs, but rather that even when there are jobs for workers of similar skill levels in the labor markets in which blacks live, those jobs are often held by whites and are less available to blacks. We term the latter hypothesis “racial mismatch.” It is most accurate to interpret what we mean by "racial mismatch" as the interaction between the spatial and the racial distribution of jobs, in contrast to pure spatial mismatch. The key difference is that we cannot have racial mismatch unless race plays an independent role in employment.

We first present evidence that is generated by estimating regression models that are consistent with "pure” spatial mismatch. In particular, we take advantage of the full file of Long-Form respondents to the Census to construct detailed, location-specific measures of the extent of jobs available to local residents. We use these measures to search for evidence consistent with spatial mismatch by estimating the effect of job density in the labor market in which blacks live on their employment probabilities, as well as estimating how this effect varies with the education level of both individuals and the jobs for which density is defined. We then turn to the substantive new question that is the core of this paper, comparing the effects on black employment of the pure spatial distribution of jobs and the spatial distribution of jobs held by blacks, and assessing which is the more important determinant.

\section{Background on Spatial Mismatch}

It is important to clarify how our research fits into the larger literature on spatial mismatch, in part to highlight the advantages of the data we use. The classic early study of spatial mismatch was by Kain (1968), who highlighted a few key empirical results using data on Chicago and Detroit: (i) that blacks were less likely to be employed in areas with lower shares of black residents (perhaps due to customer discrimination); (ii) that black employment would be considerably higher if there were less racial of labor market networks, see Bayer et al. (2005). 
segregation in housing; and (iii) that jobs had moved from central city areas to suburban areas between 1950 and 1960, thus combining with segregation of blacks in central city areas to depress further black employment prospects. ${ }^{4}$

In literature that followed Kain’s work, researchers often instead looked at employment (or earnings) differences associated with urban (central city) residence versus suburban residence (e.g., Harrison, 1972; Vrooman and Greenfield, 1980; Price and Mills, 1985; Jencks and Mayer, 1990; Kasarda, 1989; Cooke, 1996). Holzer (1991) argued that such an approach potentially improves on Kain’s because job access for blacks versus whites is likely to differ much more sharply along central city-suburban lines than along more disaggregated areas within cities; for example, blacks may have access to jobs in a central city near but not in a highly black residential area.

There are, though, a couple of obvious problems with the central city-suburban "test” (Ihlanfeldt and Sjoquist, 1998). First, job opportunities obviously vary within central city and suburban areas. Second, location is partly endogenous, and if those with jobs and therefore higher income tend to choose to live in suburban areas, ${ }^{5}$ there is a bias toward a finding of spatial mismatch in this particular test as residential distance from central city likely rises with income (Ellwood, 1986). Overall, Holzer's review concludes that the results from this line of research on spatial mismatch indicate that at least less-skilled blacks in central city areas have lower earnings and employment, differences that are "consistent with the notion of crowding in these jobs, caused by the high concentration of less-educated blacks individuals in central-city areas” (1991, p. 115). Of course, lower employment of central city blacks may also in part reflect unmeasured differences between blacks residing in central city areas and blacks (or whites) residing elsewhere. ${ }^{6}$

\footnotetext{
${ }^{4}$ However, this evidence was disputed by Offner and Saks (1971) and Masters (1974, 1975).

${ }^{5}$ As Ihlanfeldt and Sjoquist (1998) note, this will tend to occur if the income elasticity of housing demand exceeds the income elasticity of commuting cost, or if higher-income workers value the amenities and government services that may be more abundant in outlying areas.

${ }^{6}$ Wilson's (1987) work focuses on the interactions between spatial mismatch and the characteristics of the inner-city residents that remain, arguing that the movement of jobs out of central city areas contributed to the growth of the black underclass.
} 
As a partial response to the problem of variation in job opportunities within central city (and other) areas, other work on spatial mismatch has tried to incorporate more direct information on job access related to either travel time or the extent of nearby jobs within a metropolitan area (e.g., Ellwood, 1986; Hutchinson, 1974; Ihlanfeldt and Sjoquist, 1990; Hughes and Madden, 1991). ${ }^{7}$ The latter approach is closer to what we do in our tests of pure spatial mismatch, although we incorporate a good deal more information on the availability of jobs. ${ }^{8}$ These studies tend to show that blacks face lower access (such as longer commute times to jobs because there are fewer jobs per person in the areas where blacks live), but that the differences may not be large and could conceivably be overcome relatively easily (Ellwood, 1986). But as Holzer (1991) and Ihlanfeldt and Sjoquist (1998) point out, some of these studies using measures of commute times or distance from central cities may be plagued by the same problem of endogeneity of residential location that arises in work using the central city-suburb dichotomy, and the longer commute times for whites that this endogeneity generates implies that the endogeneity may lead to understatement of differences in job access faced by blacks relative to whites. In addition, if commuting to suburban jobs is difficult for blacks, it may be unusual to observe long commute times for blacks even though the potential commute times they face are in fact longer. Finally, as numerous authors have pointed out, even compelling evidence of longer commute times for blacks does not point to spatial mismatch per se, as simple employment discrimination against blacks can imply fewer job offers and hence on average longer commute times even if blacks and whites live in the same place.

The same potential problem of endogeneity applies to studies noting that blacks have poorer access to jobs and studying the link between job access and employment; in particular, people with jobs have higher incomes and may therefore chooses to live in areas with less job access, thus biasing towards zero any link between job access and employment (Ihlandfeldt, 1992). One solution to this approach has

\footnotetext{
${ }^{7}$ Kain also incorporates information on distance between ghetto areas and other areas in which blacks live.

${ }^{8}$ Ihlanfeldt and Sjoquist (1998) characterize studies using direct measures of job access as falling into one of two categories: either using a single metropolitan area with measures of job accessibility at the neighborhood level; or using many metropolitan areas, typically restricted to central cities, with a single measure of job accessibility for each metropolitan area (e.g., Kasarda and Ting, 1996; Cutler and Glaeser, 1997). The first lacks generalizability, while the second ignores considerable variation in job accessibility across neighborhoods within central cities.
} 
been to focus on youths (e.g., O’Regan and Quigley, 1996), who to a greater extent do not make their own residential decisions; but of course youths may have similar unobserved characteristics to their parents, so this may not solve the problem nor provide very generalizable results (Ihlanfeldt and Sjoquist, 1998). Moreover, once youths reach age 18 - an age at which many enter the labor market - they tend to have higher rates of mobility between geographic areas. ${ }^{9}$ Zax and Kain (1988) provide evidence that is less prone to criticisms regarding unobserved characteristics of inner-city blacks underlying apparent evidence of spatial mismatch. In particular, they examine how black and white employees responded to their employer relocating from central city Detroit to the suburbs, finding that blacks were less likely to move to the suburbs and keep their jobs, and more likely to quit.

Overall, Holzer's review of this evidence suggests that the work incorporating information on job access is consistent with employment prospects for central city blacks declining as employment shifts away from these areas (1991, p. 117); more generally, his review concludes that spatial mismatch has adverse effects on black employment. The most recent review by Ihlanfeldt and Sjoquist (1998) concludes that the evidence in favor of the spatial mismatch hypothesis is quite strong, and that if anything there are reasons to believe the existing estimates tend to understate its importance, because it is difficult to accurately measure the jobs available to any particular individual or group of individuals.

Our research touches base with the existing literature in a few ways. First, we begin with the central city-suburban test of the spatial mismatch hypothesis. However, we then introduce information on job access. Weinberg's (2002) recent work on spatial mismatch is perhaps closest to ours. Weinberg (2002) uses data from 1980 for a large set of MSA's, and estimates the effect of the percentage of the region's jobs that are in the central city, and the difference between the percentage of the black and white population living in the central city, on the difference between black and white employment rates for the

\footnotetext{
${ }^{9}$ Based on the full data set of Long-Form respondents (discussed below), young black males aged 18 to 24 are more likely to have moved within the last five years than black males aged 25 to 64. In particular, 56 percent of young black males moved within the last five years versus 49 percent of black males aged 25 to 64 . These young males are not necessarily moving within the same metropolitan area, as they are more likely to change state, MSA, county, as well as Census place than are black males aged 25 to 64. (A Census place corresponds to a city, an incorporated area that functions like a city, or an unincorporated area that does not have its own government but otherwise looks like an incorporated area.)
} 
metropolitan area. The basic finding is that when there are more jobs located in the central city area, black employment rates are relatively higher, consistent with spatial mismatch. ${ }^{10}$ Perhaps the key difference with respect to our research is that we have measures of job access at a considerably more disaggregated level, which come from non-standard, confidential Census information on place of work. In addition, because of the large sample and other features of our data, we are able to construct job access measures by skill, which may provide a better characterization of spatial mismatch facing particular groups of individuals. Finally, we focus not on black-white employment differentials, but instead - following most of the spatial mismatch literature - on the determinants of black employment. Of course, we depart from the existing literature by introducing the idea of racial mismatch, testing for it by constructing measures of job density by race and testing whether the racial distribution of jobs is also an important determinant of black employment.

\section{Data}

Our core data set for studying spatial mismatch is the 2000 Sample Edited Detail File (SEDF). ${ }^{11}$ The SEDF contains all individual responses to the 2000 Decennial Census one-in-six Long Form. The SEDF includes detailed information on residential location and place of work. Access to the entire file of Long-Form respondents via the SEDF provides a very large sample with which it is possible to construct various job density measures (described below) disaggregated by demographic characteristics and more importantly by detailed location. We also have access to the individual-level controls provided in the Census, to capture differences in skill and other characteristics across individuals that may influence the outcomes we study.

The key feature that these data provide from the perspective of studying spatial mismatch is the ability to construct measures of job density for highly disaggregated geographic units within MSA's. For any area, such as a zip code or an entire MSA, we can compute the number of jobs in the area relative to

\footnotetext{
${ }^{10}$ The results hold up when he instruments for employment centralization with information on the industrial composition of the region and for residential centralization with city-suburban differences in the age of the housing stock.

${ }^{11}$ The results are qualitatively very similar using the 1990 SEDF.
} 
the population residing there - we refer to this as the "job density." We also compute this measure for subsets of the population defined by educational attainment. In all cases, the density measures assigned to each Census respondent are calculated excluding that individual, to avoid building in a mechanical relationship between job density and an individual's employment. Job density parallels the concept of “job accessibility” that figures prominently in research on spatial mismatch, although it has been more common to measure this accessibility indirectly via commuting time. Of course the definition of these density measures requires the specification of the relevant local labor market. We focus our attention on “zip code areas,” defined by the zip code and all geographically contiguous zip codes. As noted below, single zip codes seem too small, because a relatively small share of individuals works in the zip code in which they reside. On the other hand, over a third of the individuals in our sample work in the "zip code area” in which they reside, suggesting that the zip code area (as opposed to, say, the entire MSA) captures a relatively compact geographic area in which many residents look for employment. ${ }^{12}$

Table 1 describes the construction of the sample of black males used in this paper. As shown in the top row, the full SEDF includes 42.6 million (non-institutionalized) observations, with nearly 2.2 million observations on black males. The following six rows indicate how many of these observations (on black men) would be excluded based on a number of criteria for exclusion from the sample; each criterion is considered separately, rather than specifying an arbitrary order for imposing them and the number of observations dropped at each step. The three most significant exclusion criteria are living outside a metropolitan area, being outside the age range, and (related to age) being in school. Imposing all of these criteria jointly yields 700,303 observations on black men.

The rows that follow address the implications for the sample of some particular problems that arise in our application, in which we want to be able to identify both where people live and where they

\footnotetext{
${ }^{12}$ Technically, the 2000 Decennial Census reports Zip Code Tabulation Areas (ZCTA’s) rather than the more traditional postal zip codes, although there is a one-to-one mapping of the two definitions in most cases; we therefore simply refer to ZCTA's as zip codes. Some ZCTA's are actually disjoint sets of census blocks. In those (relatively rare) cases, we treat the disjoint sets as two separate zip codes. For each zip code, we use ArcView to map the zip codes contiguous to each zip code in which an individual in our data resides, and these are our "zip code areas." A single zip code therefore is likely to be part of multiple zip code areas in our data.
} 
work. The first problem is that a small number of observations (about 2,800) report a zip code for either place or work or place of residence that is on the water, rather than on land. For example, an oil rig would be a work location on the water. These zip codes have very few residents or workers (and often only one or the other) and therefore have meaningless measures of job density, so we exclude these zip codes from our analysis.

A more significant problem is either unmatched or allocated information on place of work. Unmatched information arises when one's place of work is in a zip code that does not get included in the file we use to create contiguous zip codes; this problem is relatively minor. Far more prevalent are cases where the place of work has been allocated rather than reported by the respondent, which happens about one-fifth of the time. Because we want to be sure to accurately measure place of work, and because our examination of the allocated cases suggested that allocated places of work are essentially chosen to be random places within CMSA's/MSA's, we drop these cases. However, because the incidence of missing place of work information is non-random with respect to observable characteristics, we do not want to ignore this problem altogether. Therefore, for the sample of employed workers, we also estimated a linear probability model for unmatched or allocated place of work information as a function of all of the demographic controls used in the regressions described below. We then reweighted the employed observations based on the estimates from this model, weighting by the reciprocal of the predicted probability of having valid place of work data. The resulting weighted sample with place of work data is therefore representative of the sample with or without these data. These weights are used in all descriptive statistics and regressions reported below.

The final set of sample restrictions ensures that the job density measures are well-defined, or defined at all. In particular, because the denominators of the density measures are the numbers of individuals with given characteristics living in the zip code area, these denominators can sometimes be zero. The resulting sample size for any particular regression would depend on which density measures we are using. Instead, we chose to drop these all zip code areas with undefined density measures for all of the 
regressions we estimate, so that the various estimates can be compared across a consistent sample. ${ }^{13}$ The final number of SEDF observations on black men is 533,198.

As noted above, we define our job density measures for zip code areas defined for each zip code and those that are geographically contiguous. The idea here, as explained in more detail below, is to think about a geographic unit in which the availability of jobs has an important influence on residents of that geographic unit. As mentioned previously, a city (or MSA/PMSA) is likely way too large. On the other hand, single zip codes are likely too small. To be more specific, the last three rows of Table 1 show that about 14 percent of employed black men work in the zip code in which they live, and 92 percent work in the same MSA/PMSA. In contrast, 34 percent of employed black men live and work in the same zip code area. Thus, zip code areas seem a reasonable middle ground - large enough to capture a meaningful local labor market, but small enough to also capture differences in the distribution of jobs across sub-areas of cities.

\section{Empirical Approach}

\section{Spatial Mismatch}

The analysis of spatial mismatch uses the sample of black men in the SEDF living in MSA's. We begin with what is perhaps the simplest type of specification in the spatial mismatch literature, estimating the employment differential associated with residence in central city areas. The expectation from the spatial mismatch hypothesis is that black men in central cities will face worse employment prospects because they tend not be located near jobs. The identifying assumption in this regression is that blacks, because of constraints of one form or another (housing discrimination, capital market constraints, etc.), are confined residentially to certain geographic areas, so that central city residence is exogenous. Of course the same type of identifying assumption carries over to the other regressions we estimate examining the effects of the spatial (or racial) distribution of jobs on black male employment.

The specification we estimate is

\footnotetext{
${ }^{13}$ We also perform a robustness check where we exclude zip code areas where the denominator is formed by fewer than 10 residents.
} 


$$
E=\alpha+X \beta+\gamma C C+\varepsilon .
$$

where $X$ is vector of individual-level control variables, including age (linear and quadratic terms), marital status (a dummy variable for currently married), education (five dummy variables for high school degree, some college, Associate’s degree, Bachelor’s degree, and advanced degree), and Census region (South, West, Northeast, and North Central). These individual controls are important to account for differences in the composition of the population of central city areas. $C C$ is a dummy variable for central city areas of MSA's. Although neither shown here nor reported in the tables, the specifications also include a control for the very small fraction (fewer than one percent) of the sample that resides in another urban area of an MSA; however, the key contrast is between the central city and the suburbs. Given the sample size, equation (1) is estimated as a linear probability model.

What equation (1) does not capture, however, is the presumption in the spatial mismatch literature that the location of jobs is more relevant for less-skilled individuals, due to lower wages net of commuting costs and greater reliance on public transportation. We therefore augment the model to allow the effects of central city residence to vary with education levels of individuals, as in

$$
E=\alpha+X \beta+\Sigma_{k} \gamma_{k} C C \cdot E D_{k}+\varepsilon,
$$

where $E D_{k}$ is a dummy variable for whether the individual has education level $k$, and $\gamma_{k}$ is the coefficient on central city residence for individuals of each educational level $k \cdot{ }^{14}$ We would expect the effects of central city residence to be most adverse at lower educational levels, if the spatial mismatch story is accurate and the central city effect actually reflects lower availability of jobs in the areas where blacks live.

While the central city-suburb split is common to one strand of research on spatial mismatch, it is an indirect way to characterize the job opportunities facing different individuals, and therefore may not do much to capture spatial mismatch. We therefore estimate regressions that should more directly capture the

\footnotetext{
${ }^{14}$ We experimented with varying levels of detail, but settled on using categories for less than high school, high school graduate, and any (some) college. As the results below show, most of the important relationships appear for the lowest levels of education, so there was nothing gained by further disaggregating those with different amounts of post-secondary education.
} 
essence of spatial mismatch by including measures of job density, measured at the level of contiguous zip code areas. We first estimate specifications that simply add an aggregate job density measure to equation (1), as in

(3) $\quad E=\alpha+X \beta+\gamma C C+\delta J D+\varepsilon \cdot \cdot^{15}$

This specification captures the basic implication of the spatial mismatch model - namely, that job density should be an important determinant of employment. So we expect to find a positive estimate of $\delta .^{16}$

Equation (3) does not capture the presumption in the spatial mismatch literature that the location of jobs is more relevant for less-skilled individuals. We augment the model to allow the effects of job density to vary with education levels of individuals, as in

$$
E=\alpha+X \beta+\gamma C C+\Sigma_{k} \delta_{k} J D \cdot E D_{k}+\varepsilon .
$$

We would expect the effects of job density to be largest at lower educational levels, if the spatial mismatch story is accurate and the job density effects actually reflect influences of the availability of jobs in the local labor market.

While equation (4) allows for different effects of overall job density depending on individuals’ skill levels, it may inaccurately capture the effects of job density on individuals in different skill groups because it uses an aggregate job density measure, rather than a measure of density of jobs at the same skill level of the worker. We therefore try to obtain a sharper test for spatial mismatch by constructing education-specific job density measures - in particular, for those with at most a high school degree, and for high school dropouts. When we construct these job density measures for lower education levels, the restriction applies to both the numerator and the denominator; for example, the high school dropout job density measure is jobs held by high school dropouts divided by residents who are high school dropouts. Thus, equation (4) becomes

\footnotetext{
${ }^{15}$ In all cases, because the data are clustered on zip code areas and the job density variables are defined at this level, we report standard errors that are robust to non-independence of observations within zip code areas, as well as heteroscedasticity. We also present results that add MSA fixed effects to the regression models. (The estimates of equations (1) and (2), unlike the equations that follow, do not use any variables defined at the zip code area level, but we still report clustered standard errors to be comparable with the estimates of the job density equations.)

${ }^{16}$ We still include the central city (and other urban area) controls, but now focus explicitly on the effects of jobs per
} 


$$
E=\alpha^{j}+X \beta^{j}+\gamma^{j} C C+\Sigma_{k} \delta_{k}^{j} J D_{j} \cdot E D_{k}+\varepsilon_{j}, j=1, \ldots, J,
$$

where the job density measure now has a $j$ subscript to indicate that it is defined for a particular education level, and the parameters have a $j$ superscript (and the residual a $j$ subscript) to indicate that we estimate the model separately for job densities defined for different education levels $j$. Under the spatial mismatch hypothesis, we expect to find the strongest evidence that job density affects employment when we use job density defined for low education groups and how this job density measure affects employment of lesseducated black men. We also estimate equation (3) for job densities defined for different education levels.

Thus, the estimates of the models captured by equations (1) through (5) take us through a sequence of increasingly detailed models that test the spatial mismatch hypothesis. The overall results, and how they change with the specification, provide more compelling tests of the effects of spatial mismatch than has much of the previous literature.

\section{Racial Mismatch}

The specifications to this point do not distinguish job density by whether the jobs are held by blacks or whites. The key question with which this paper is concerned, however, is whether employment is more sensitive to job density for one’s own race - in contrast to the simple spatial mismatch hypothesis, but consistent with important roles played by discrimination or labor market networks.

To study this question, we first go back to the simplest specification (equation (3)) incorporating measures of job density, but distinguishing job density by race. This specification is

$$
E=\alpha+X \beta+\gamma C C+\delta^{W} J D_{W}+\delta^{B} J D_{B}+\varepsilon .
$$

In this specification we include two disaggregated job density measures: $J D_{W}$, which is white jobs per black resident; and $J D_{B}$, which is black jobs per black resident. We actually use three alternative versions of these density measures: jobs held by non-blacks and jobs held by blacks, per black resident; jobs held by non-black men and jobs held by black men, per black male resident; and jobs held by white men and jobs held by black men, per black male resident. But we refer simply to black and white job density as a short-hand.

resident. 
Note that this specification allows black and non-black (or white) job density to affect black employment separately. Because we define both densities relative to black residents, estimates of the two coefficients $\delta^{W}$ and $\delta^{B}$ allow a comparison of, for example, the effect on black employment probabilities of an additional black job per black resident to the effect of an additional white job per black resident. If job density of one's own race is more important, then we should find that $\delta^{B}>\delta^{W}$ (with the first expected to be positive), indicating that black job density does more to boost black employment. This would be evidence against pure spatial mismatch (which would instead predict no difference between $\delta^{W}$ and $\delta^{B}$ ), and instead point to racial mismatch in the sense that black employment problems may reflect not so much the availability of jobs - at the right skill level in the specifications that distinguish by skill, described below - but rather jobs that are present but unavailable or less available to blacks.

We also estimate versions equations (4) and (5) allowing for separate effects of job density by race. These specifications become

$$
E=\alpha+X \beta+\gamma C C+\Sigma_{k} \delta_{k}^{W} J D_{W} E D_{k}+\Sigma_{k} \delta_{k}^{B} J D_{B} \cdot E D_{k}+\varepsilon
$$

and

$$
E=\alpha^{j}+X \beta^{j}+\gamma^{j} C C+\Sigma_{k} \delta_{k}^{j, W} J D_{j, W} E D_{k}+\Sigma_{k} \delta_{k}^{j, B} J D_{j, B} \cdot E D_{k}+\varepsilon_{j}, j=1, \ldots, J,
$$

where $J D_{j, B}$, for example, is jobs held by blacks with education level $j$ per black resident with education level $j$. Again, comparisons of the estimated $\delta$ 's tell us whether the effects of job density are race specific.

\section{$\underline{\text { V. Results }}$}

\section{Descriptive Statistics}

The top panel of Table 2 reports descriptive statistics on residence and education of black, nonblack, and white men. The means show that $58 \%$ of black men, but only $30 \%$ of non-black men and $27 \%$ of white men live in central city areas, reflecting the rather profound residential segregation that is at the core of the spatial mismatch hypothesis. The means also reveal the rather sharp educational differences between blacks and non-blacks or whites, with a much higher incidence of education less than high school (more than double the rate for whites), and a considerably higher incidence of post-secondary education for non-blacks (57\%) and whites (62\%) than for blacks (42\%). 
Panel B reports on overall job density, providing comparisons for blacks and whites. ${ }^{17}$ Average overall job density is higher for black men, whether defined as overall job density, job density for males only, or job density for black and white males only. For example, using the overall job density measure, the average faced by blacks is 0.77 , versus 0.73 for whites. The difference is larger (0.07) for male job density, and larger still (0.10) for black and white male job density. This difference implies that, on net, there are more jobs per person in the areas in which blacks live, presumably reflecting net commuting patterns into central city areas. The numbers at the median, $25^{\text {th }}$, and $75^{\text {th }}$ percentiles reveal that this is primarily a function of differences in the upper tail. For the overall job density measure, the median is the same for blacks and whites, and the $25^{\text {th }}$ percentile is higher for whites, whereas the $75^{\text {th }}$ percentile is higher for blacks. For the other two density measures the relationship does not flip at the different quartiles, but the gap is always larger at the median than at the $25^{\text {th }}$ percentile, and larger still at the $75^{\text {th }}$ percentile. These differences are likely driven by particularly high job density in heavily urban areas. Note that the numbers in Panel B contradict the basic summary of the spatial mismatch hypothesis quoted in the Introduction, that "there are fewer jobs per worker in or near black areas than white areas.” However, taking a more nuanced perspective that conditions on skill, Panels C and D report job density figures broken down by education level - first for those with at most a high school degree, and then for high school dropouts. Although, as just noted, overall job density using all jobs and residents is higher for blacks, job density for the lowest education category (less than high school) is lower for blacks ( 0.50 versus 0.66 ), as it is if job density based on a high school degree or less ( 0.66 for blacks versus 0.74 for whites); the same conclusion holds if we look only at males or only at black and white males. In contrast, job density for those with some college (not shown in the table) is higher for blacks ( 0.95 for blacks versus 0.77 for whites), based on the first measure, and similarly for the others. The higher density at the highest education level, and lower density at lower education levels, highlight spatial mismatch in terms of skills, in that blacks, who are less educated, live in areas where high-skill job density is high relative to areas where whites live, while low-skill job density is relatively low. Nothing in

\footnotetext{
${ }^{17}$ The figures for non-blacks, not reported in the table, are very similar to those for whites.
} 
these estimates directly shows that it is whites rather than blacks who tend to come into these areas to work, but given the lower education of blacks coupled with evidence on commuting patterns into central cities, it is clear that more highly-educated workers are being "imported” into black areas (i.e., the areas in which blacks tend to live, and which are therefore disproportionately represented in the black sample).

Table 3 reports job density figures by race. These job density measures are used to capture "racial mismatch" rather than simply "spatial mismatch.” Recall that when we measure, for example, white male job density for blacks, we divide the number of jobs held by white males in the zip code area by the number of black male residents. It is clear in the overall figures in Panel A that do not disaggregate by education that, as we would expect given the small share of the black population, on average blacks are exposed to a much higher non-black job density than black job density. For example, the mean of nonblack jobs per black resident is 6.11, versus a mean of black jobs per black resident of 0.61 ; the medians reflect a similar difference, although not as extreme as at the means because of the upper tail. The high value of non-black or white job density for black workers indicates that whites often hold many jobs in areas where blacks live; moreover, this is disproportionate to their share in the population of residents where blacks live. $^{18}$

The much higher non-black job density does not necessarily imply, however, that there are many jobs available to blacks in the areas in which they live, because many of the jobs may require skill levels higher than those of local blacks. We would certainly expect this to some extent given the lower educational levels of blacks reported in Table 2. It is of interest, then, to compare the race-specific job density measures disaggregated by education level, which we do in Panels B and C of Table 3 - again, first for those with at most a high school degree, then for high school dropouts only. The differences between non-black and black job density faced by blacks fall, indicating that the jobs held by non-blacks in areas where blacks tend to live employ more-educated workers. For example, in Panel C, for dropouts

\footnotetext{
${ }^{18}$ For example, we computed, for blacks, the mean of white male residents per black male resident, and the mean of white male jobs per black male job, based on zip code area of residence. The ratio of white male jobs to black male jobs exceeded the ratio of white male residents to black male residents by $25 \%$ ( 7.54 versus 6.05$)$. At the lowest schooling level, the comparable numbers are $26 \%$ (4.32 versus 3.42). In all cases, these means are computed over all blacks for which both the job and resident densities can be defined (i.e., the denominators are nonzero).
} 
only, the average non-black job density is 4.30 (versus 6.11 across all education groups), while the average black job density is 0.46 (versus 0.61 across all education groups); at the medians the differences are smaller still. Nonetheless, it is still the case that white job density is considerably higher than black job density for these education-specific job density measures, so that less-educated blacks do live in areas where there are many jobs held by less-educated whites. At the means, there are about 3-5 such jobs per black resident, and at the medians this range falls to about 0.8 to 1.8 .

Overall, Tables 2 and 3 convey a few messages. Looking first at job density without regard to the race of workers, jobs are relatively plentiful in areas where blacks live. On its own, this is not inconsistent with the spatial mismatch hypothesis, since there may still be spatial mismatch at the more disaggregated skill-specific level. Indeed, to some extent, blacks are mismatched with the skills needed for jobs in their zip code area; blacks are less educated than whites, and at the same time Panels B-D of Table 2 show that education-specific job densities are lower for blacks. On the other hand, looking at job density figures by race, it is clear that there are many jobs held by non-blacks in areas where blacks live - including at lower educational levels. This suggests that the problem may not be a lack of jobs at appropriate skill levels where blacks live, but a lack of jobs that are available to blacks. The regression results reported in the next two sub-sections explore more formally the relationships between the spatial and racial distribution of jobs and employment outcomes.

\section{Spatial Mismatch Regressions}

Having discussed the descriptive statistics, we next turn to the regression results for employment. We begin, in Table 4, with regressions that follow the literature that tests for spatial mismatch by using the variation in employment differentials based on central city residence. In column (1) of Table 4, which reports estimates of equation (1), we see one "standard" spatial mismatch result that residence in the central city is associated with significantly lower employment prospects for blacks. In particular, for black men the employment "penalty” associated with central city residence is 0.059 (or 5.9 percentage points), 
and the estimate is strongly significant. ${ }^{19}$

Because the spatial mismatch hypothesis predicts that central city residence is more of a deterrent to employment of those with lower skills, column (2) reports estimates of equation (2), where we interact the dummy variable for center city residence with dummy variables for educational level. The results are consistent with expectations. For the least-educated (high school dropouts), central city residence is associated with an employment rate that is lower by 0.084 , declining to 0.071 for high school graduates and 0.037 for those with some college. Given that employment rates rise with schooling, the differences in the implied percentage effects on the employment rate would be even larger.

We also estimated these two models with MSA fixed effects, absorbing any unmeasured MSAlevel differences that might be correlated with central city residence and employment, and identifying the effect of central city residence solely from within-city variation. ${ }^{20}$ This led to very similar estimates and standard errors; in all cases the estimated coefficients of the central city variables were slightly larger in absolute value (not reported in tables).

We next turn, in Table 5, to estimates of equations (3), (4), and (5), which include overall or education-specific job density measures without distinguishing the density measures by race. ${ }^{21}$ The top panel of Table 5 reports estimates of equation (3), using a single job density measure with no interactions with the individual's education level. There are, though, two dimensions of variation across the nine columns of the table. First, we define density in three different ways: total jobs per resident; jobs held by males per male resident; and jobs held by black or white males (only) per black or white male resident. We have no strong prediction about how the estimated effects should vary across these density measures but we want to explore the robustness of the results to the different measures, all of which seem

\footnotetext{
${ }^{19}$ Given the large sample sizes, nearly all of our results are strongly statistically significant, so in the ensuing discussion we avoid continually referring to the statistical significance of the results unless the conclusions differ.

${ }^{20}$ For example, cities with lower skill levels, on average, could have more central city residents and also lower employment rates because of lower skills. The MSA fixed effects also capture dependence between observations in the same MSA that could bias the standard errors, a problem that could be addressed in isolation by clustering at the MSA level.

${ }^{21}$ Because we view this is a better way to test for spatial mismatch, we no longer report the central city employment differentials, the interpretation of which become less clear once we include the job density measures.
} 
potentially relevant. Second, we alternatively define this density based on all individuals, and then those restricted to lower schooling levels: those with at most a high school degree, and high school dropouts only. Here, we have a strong presumption - based on the spatial mismatch model - that job density defined for lower education levels should be a much more important determinant of employment, since the density measure defined for lower educational levels better captures the relevant job density for those more likely to be constrained to work in an area nearer their residence.

The estimates in the top row of Table 5 indicate a positive effect of job density on employment. In all cases where the density is defined for either of the two lower education groups, the effect is strong and statistically significant. For the overall density measure the effect is positive but much smaller, and is only significant in column (1). So the evidence uniformly points to a stronger effect of job density when it is calculated for jobs held by those with lower levels of education as a fraction of residents with those same levels of education. Moreover, the point estimates are always larger when job density is defined for those with less than a high school education compared to when it also includes those with a high school degree.

To interpret the estimates, in column (9), for example, the implication is that a 0.1 (or 10 percentage point) increase in job density for high school dropouts, which according to Table 3 is less than the difference between the $25^{\text {th }}$ percentile and the median or the median and the $75^{\text {th }}$ percentile, raises the probability of employment by 0.0066 , or 0.7 percentage point. This is a non-trivial effect. The mean employment rate for black men, reported in Table 2, is 0.67 , so this is about a 1-percent increase in the employment rate, or an elasticity of about 0.1 .

The specifications reported in the remaining rows of Table 5 distinguish the effects of job density on employment based on an individual's own educational level, reporting estimates of equation (4) (in columns (1), (4), and (7)) and equation (5) (in the other columns). The spatial mismatch hypothesis would predict that job density should matter more for less-educated workers, and that this should be particularly true when the job density measure is constructed from the sample of individuals with lower education levels. The estimates largely confirm this expectation. In all cases where job density is defined for the 
less-educated groups, we find a positive effect of job density on employment (e.g., the 0.128 estimate in column (3)), and this effect is always larger for the less-educated groups than those with some college. In fact, there is further confirmation in the sense that in columns (2), (5), and (8), which define density based on those with at most a high school degree, the strongest effect of job density is for those with a high school degree (e.g., the estimate of 0.051 in column (5), versus the estimate of 0.044 for high school dropouts and 0.028 for those with some college), while in columns (3), (6), and (9), which define density based on high school dropouts, the strongest effect of job density is for that group. Furthermore, the strongest effects are found for high school dropouts, when we define job density based on high school dropouts (e.g., the estimate of 0.101 in column (9)); this, too, is what we would expect based on the spatial mismatch hypothesis. On the other hand, job density defined for workers with at least some college is quite weakly related to employment outcomes, presumably reflecting the fact that moreeducated labor is less tied to a narrow location in the labor market.

It might appear curious that we find effects of education-specific density measures for individuals with other education levels - for example, the 0.097 estimate in column (9) for the effect of job density defined for high school dropouts on those with a high school degree. However, we do not include the density measures for workers with a high school degree in this regression, and the densities of jobs at different education levels are positively correlated. In addition, of course, there are not rigid lines between jobs at specific skill levels and the skill levels of workers; for example, a greater prevalence of jobs filled by those with less than a high school degree may nonetheless boost employment prospects of those with a high school degree even in these jobs.

The regression estimates in Table 5 establish that the availability of jobs in one’s residential area affects prospects for employment, especially the availability of jobs at a similar skill level, and especially among the least-skilled who did not complete high school or completed at most high school. This strikes us as a sensible way to think about how location affects employment opportunities. A competing explanation is that employment rates are higher in areas in which residents are more employable based on a set of unobserved characteristics, so that the finding that job density affects employment need not reflect 
the causal effect of variation in the spatial distribution of jobs. While we obviously cannot control for all characteristics of workers, given the relatively rich set of controls we do include we are more inclined to interpret the variation in job densities as reflecting spatial influences. Moreover, the evidence of stronger effects of the spatial distribution of jobs for those with less skill is an implication of the spatial mismatch model that does not derive nearly as naturally from the hypothesis of unobserved characteristics, given that there is no obvious reason that job density should serve as a stronger proxy for these unobservables for those with fewer skills.

\section{Racial Mismatch Regressions}

The regressions in Table 5 reflect pure versions of the spatial mismatch model, in which residential location matters because of the availability of jobs for residents regardless of race, especially at lower skill levels. Now, in contrast, we explore whether there is a racial dimension to the effects of job density. That is, are an individual's employment prospects - perhaps especially at low skill levels driven more by the availability of local jobs for members of one’s own racial group? This is tested based on estimates of equations (3’)-(5') that parallel those estimated in Tables 5, but now considering the impact of two forms of job density measures: the number of non-black (or white) jobs per black resident; and the number of black jobs per black resident. ${ }^{22}$

The coefficients of each of the two density measures in each regression are directly comparable, in the sense that they compare the effects on black employment probabilities of adding either one more black job or one more non-black job per black resident. In particular, we do not expect the effect of black job density to be higher because there are more whites than blacks in the population of eligible workers, if the racial composition of jobs in an area does not independently affect employment prospects. A concrete example of what we are testing for is provided by the following example. Suppose that a new firm is created in an area, with 10 jobs, and suppose that 9 of these jobs are filled by non-residents. We are told

\footnotetext{
${ }^{22}$ Note that, relative to the job density measures in Table 5, these two density measures utilize a different denominator defined only by black residents. We do this to isolate the role of job availability for black residents, rather than for all residents. As a result, the scale of the density measures in Table 6 is much larger than in Table 5. See the summary statistics in Tables 2 and 3.
} 
the racial mix of the 9 non-resident hires, and asked whether we can predict whether this new firm increases the probability that a random black in the area is employed. If racial mismatch matters, then this probability increases more if the 9 other hires are black than if the 9 other hires are white (i.e., the new firm increases black job density, rather than increasing white job density). The same argument holds if 9 hires we are told about are not restricted to non-resident hires, as long as we leave the individual out of the calculation. ${ }^{23}$

To begin, columns (1), (4), and (7) of the top panel of Table 6 report results of equation (3'), where we simply use an overall job density measure (not distinguished by education), although broken down by race. In column (1), the two density measures are non-black and black jobs per black resident; in column (4), they are male non-black and male black jobs per black male resident; and in column (7) they are, instead, male white jobs and male black jobs per black male resident. The estimates in these three columns indicate very clearly that it is only the job density for blacks that substantively affects employment of blacks. In each case, the estimated coefficient on the black job density measure is larger than that of the non-black job density measure, by a factor of 9 to 10 . Nonetheless, the estimated effects of black job density on employment, ranging from 0.009 to 0.010 , are small, and imply that a 0.1 higher density increases the probability of black employment by only 0.001 , or 0.1 percentage point.

Next, just as we did in considering the pure spatial mismatch hypothesis, we measure job density for lower educational levels - first for at most a high school degree (columns (2), (5), and (8)), and then for high school dropouts (columns (3), (6), and (9)). We find that the estimated effects of non-black or white job density are little changed, rising by at most 0.001 . The estimated effects of black job density are higher, rising by about 0.005 for the broader low-education group, and about 0.008 using the narrower low-education group.

The lower panel of Table 6 reports results in which we augment the specification by adding interactions of the race- and education-specific job density measures with dummy variables for

\footnotetext{
${ }^{23}$ In fact, all of the qualitative results we present in Table 6 are robust to calculating job density measures by excluding from the numerator all jobs held by residents, and instead defining job density as non-resident jobs per black resident.
} 
individuals' education levels. The most important finding is that, regardless of the education level for which density is measured, the effect of black job density on black employment is much stronger than the effect of the corresponding non-black or white job density. For example, in column (3), the estimated effect of non-black job density defined for high school dropouts on employment of black high school dropouts is 0.001 , whereas the estimated effect on this same group of black job density defined for high school dropouts is 0.046 . In general, for those with some college, the difference is roughly a factor of 10 . But for those with less education, the difference is much larger, and in particular for the specifications defining job density for less-educated individuals, the difference is sometimes a factor of 20 , 30 , or even 40 or more.

The second finding that emerges across all of the estimates is that the effect of black job density for less-educated blacks is stronger when this job density is defined for less-educated jobs and residents. For example, in the second row of the lower panel, the estimated effect of black job density on high school dropouts rises from 0.009 in column (1) to 0.046 in column (3). This always holds for the interactions with the dummy variables for the two lower education levels, but the same is not true for those with some college. Moreover, the estimated effect of black job density is particularly strong for less-educated blacks, when using the density measures defined for lower education levels. The 0.046 estimate in column (3) implies that if black job density for high school dropouts increases by 0.1 , the black high school dropout employment rate increases by 0.0046 , or 0.46 percentage point. Given an employment rate of (coincidentally) 0.46 for black high school dropouts, this represents an increase of 1 percent, or an elasticity of 0.1 . At the same time, this elasticity is well below 1 , indicating that the benefit of higher job density does not accrue solely to residents. Importantly, in contrast, we do not find the same sort of results with respect to the effects of non-black or white job density on black employment. Higher non-black or white job density has little effect on black employment probabilities, and generally fails to exhibit the differences in effects associated with education that are predicted by the spatial mismatch hypothesis. This evidence is consistent with the spatial mismatch notion that job density matters for the employment of less-educated blacks, but it is only the spatial distribution of jobs held by blacks that 
matters - which we have termed racial mismatch. ${ }^{24}$

\section{Robustness and Possible Biases}

There are a number of issues regarding measurement of our variables, or possible sources of spurious or non-causal correlations, which could affect our estimates or how we interpret them. First, Raphael (1998) argues that the flow of new jobs better captures job availability than the stock of jobs as embodied in job density measures like the ones we use. In his work - which addresses pure spatial mismatch - he instead uses job creation rates to measure job availability, based on employment change between the 1980 and 1990 Censuses. However, even if Raphael is correct that job changes matter more than job levels for characterizing the spatial distribution of employment opportunities, unless the relationship between job flows and stocks differs in jobs held by blacks and jobs held by whites, the fact that we use a stock measure of job availability rather than a flow measure cannot explain the difference in the impact of job density by race in our estimates. This argument echoes one we make a few times in this subsection. In particular, although one can think of reasons why the estimated coefficients on job density measures in our regressions corresponding to pure spatial mismatch may be biased estimates of the effects of the local availability of jobs, it is far less clear why there is any bias in our estimated differences between the estimated coefficients of the white and black job density measures.

A second potential concern is measurement error in the job density measures. In particular, if we end up with a zip code area with very few black men (the most likely problem, given their small share of the population), then there could be non-negligible measurement error in the estimated job density rates. Unlike the textbook measurement error case, the implications for bias in the estimated coefficients are unclear, because we always have more than one density measure included in the equation, and in the case

\footnotetext{
${ }^{24}$ Because the spatial mismatch hypothesis takes constraints on black residential location as its starting point, and focuses on explaining black employment based on characteristics of the labor markets in which blacks reside, we have focused on blacks throughout this paper. For whites, in contrast, we would expect the results to be more reflective of endogenous residential location choice. Nonetheless, it might be of interest to consider what happens when we estimate specifications for white male employment comparable to those in Table 6, but including measures of white and black jobs per white resident. In key respects, the results are qualitatively similar to those for blacks. White job density in one's skill group boosts employment, and does so more for less-educated than more-educated whites. Black job density does not boost white employment. However, the estimated coefficients on black job density were negative rather than zero. This likely reflects negative selection on unobservables among whites who,
} 
of the lower panel of Table 6 we also have interactions between these density variables and education. To assess the potential influence of measurement error on the estimates, we re-estimated our models dropping from the sample zip code areas for which density measures were based on fewer than 10 black men. Column (2) of Table 7 reports the estimates for the specification corresponding to the last column of Table 6 - using black and white men with less than a high school education to define job density. (The baseline estimates from Table 6, with which these can be compared, are repeated in column (1).) In the top row, using job density measures without the education interactions, the estimated effect of white job density rises, and that of black job density falls, although the latter still remains nearly twice as large. For the estimates in the bottom panel that include the education interactions, the estimated effects of job density based on high school dropouts are actually larger in all cases for high school dropouts and for those with at most a high school degree, but not for those with some college. For the two low-education groups, for which the spatial distribution of jobs should be more important, the absolute differences between the estimated effects of black and white job density increase, while the relative differences fall. Thus, we regard the evidence for the two low-education groups as largely unchanged. ${ }^{25}$

A third potential measurement issue regards the definition of a local labor market, which we have defined as the zip code of residence and all contiguous zip codes. Of course any such definition is arbitrary and at best an approximation. Given that we found that about one-third of workers are employed in the local labor market based on this definition, it is possible that we understate job density for any particular resident, since the relevant labor market must extend somewhat further. In this case, for the regressions corresponding to pure spatial mismatch, the estimated effect of job density - as an estimate of the effect of job density in the relevant labor market - is upward biased, as an increase of one measured job per resident represents in increase of more than one actual job per resident. Moreover, the error in defining a local labor market likely depends on the geography of where a person lives. Thus, if blacks and

conditional on white job density, live in areas where there are few white residents and many jobs held by blacks.

${ }^{25}$ In addition to this robustness check, we verified that the estimates and conclusions were robust to omitting the weighting to correct for the non-representativeness of the sample with valid place of work, and using OLS standard errors. We also did many of these robustness checks for the pure spatial mismatch tests in Table 5, and found, 
whites live in different types of areas, causing the mismeasurement of the local labor market to differ by race, then any comparisons of the effects of job density across races might be misleading. Note, however, that this pertains to estimates of the effects of overall job density measures on employment of blacks and employment of whites. This is not what we do, however. Instead, we estimate the difference in the effects of black and white job density on black employment. There is no obvious reason why mismeasurement of the local labor market should bias the estimated difference between these two effects, although such a bias could arise if there is a difference in the share of white jobs versus black jobs that is in the measured versus the true local labor market. To assess this issue, we re-estimated our racial mismatch regressions excluding suburban residents, for whom geography and hence the definition of the relevant labor market may be quite different from city residents. The evidence for the same specification discussed above is reported in column (3), and is qualitatively similar to that from the baseline specification, with a slight diminution of the estimated differences between the effects of black and white job density.

A fundamental issue of concern is whether these specifications likely reflect causal effects of job density (race-specific) or instead reflect spurious or endogenous influences. One potential explanation for our findings is that there is variation in reservation wages across geographic areas, and the patterns differ by race. For example, in areas in which blacks have low reservation wages, relatively more blacks should be employed, leading to higher job density, and any individual black should be more likely to be employed. It is not clear what should drive geographic variation in reservation wages of blacks, and if the variation were the same in reservation wages of non-blacks or whites, then this would not explain our findings, since a low reservation wage area should exhibit higher job density of all racial groups, as well as higher employment probabilities for individual blacks. Nonetheless, it is possible that variation in policies pertaining to welfare, unemployment compensation, criminal justice, etc., affect reservation wages of non-blacks and blacks differently, either because the policies directly influence different races differently, or do so through mediating influences of other variables for which we do not control (such as variation in the effects of welfare depending on family structure).

similarly, that the results in that table were very robust. 
To control for the effects of policy variation, we re-estimated the models in Table 6 including, alternatively, state fixed effects and MSA fixed effects, as the relevant policies could be either state or local. The results, reported for the same specification as for the measurement analyses discussed above, are reported in columns (4) and (5) of Table 7, and indicate little change in any of our estimates. It is true that policies could also vary within an MSA, but such policies may well affect workers throughout the MSA. Moreover, given how insensitive the estimates are to including state or MSA fixed effects, it seems extraordinarily unlikely that policy variation within MSA’s plays a non-negligible role.

The specifications for MSA fixed effects are also informative regarding potential biases in our standard errors owing to spatial correlations of observations. Although we cluster on zip code areas, there can clearly be dependence among observations on nearby zip code areas. These can arise because of common unobservables that have a spatial component. In addition, because individuals are counted in the job density measures for more than one zip code area - given that zip code areas are defined as a core zip code and all contiguous zip codes - measurement error in the job density estimates may be correlated across zip code areas. The simplest way to address this spatial correlation problem is to cluster the observations at the MSA level, allowing for arbitrary correlation between observations across zip code areas in an MSA. The inclusion of MSA fixed effects takes this one step further, by allowing for MSAlevel unobservables that are correlated with the regressors, but also, clearly, capturing any dependence across observations within the same MSA. ${ }^{26}$

Finally, as noted earlier, the spatial mismatch literature has sometimes reflected concern with the endogeneity of location choices which are taken as exogenous in most of the empirical work in the literature as well as in the regressions we have estimated thus far. In tests of pure spatial mismatch, this is a more serious problem, as those with stronger tastes for work, or higher market productivity, may choose to locate in areas with more jobs, hence generating a positive association between job density and

\footnotetext{
${ }^{26}$ One could also imagine a more explicit model of spatial autocorrelations among zip code areas. Any such model would be both complicated and ad hoc in our context. It would offer potential efficiency gains, conditional on correct model specification. But given that our standard errors are so small, even with the MSA fixed effects, there seems little value to these potential efficiency gains.
} 
employment probabilities. However, this factor, in and of itself, cannot explain why there is a much larger coefficient estimate on black job density than on white job density, as the blacks with stronger tastes for work should relocate to areas with higher job density irrespective of the racial composition of those jobs. Rather, our findings could be generated by endogeneity only if blacks with stronger tastes for work (or higher productivity) tend to move to areas where there are relatively more jobs employing blacks. But the results would still imply that these blacks are not, to the same extent, moving to areas where there are relatively more jobs employing non-blacks. In that sense, even if blacks with stronger tastes for work were moving to areas with higher black employment rates, the results, while no longer interpretable as causal, would still demonstrate the importance of the race-specific spatial distribution of jobs, rather than the spatial distribution of jobs per se.

Nonetheless, we can also shed some light on whether our results are driven by mobility, which we do in columns (6) and (7) of Table 7. There, we break the sample into those who did not change residence in the last 5 years, and those who have moved. We do find a stronger relationship between black job density and employment probabilities for black males among those who moved, suggesting that this kind of endogenous mobility may partly drive our results. However, we also find similar qualitative evidence regarding the effects of race-specific job densities for those who have not moved in the last 5 years. We cannot interpret this sample as representing effects for individuals who are completely immobile, but it does represent those who are clearly less mobile, and given that low-skilled workers are likely to be in relatively high turnover jobs, it seems reasonable to view residential location for this sample as predetermined with respect to employment. In general, therefore, our evidence on the effects of racespecific job density is very robust, and does not appear to suffer from biases that might generate spurious evidence of racial mismatch. ${ }^{27}$

\footnotetext{
${ }^{27}$ Although we have reported the results only for the specification corresponding to column (9) of Table 6, we have examined all of the results for these alternative analyses. The estimates for the other definitions of job density were also similar to those reported in Table 6 . The only two exceptions were for the analysis of non-movers, and the analysis excluding suburban residents. In these two cases, when job density was defined for all education levels, the estimated effects of black job density were no larger than those of white job density, and in a couple of cases were smaller (and for the non-suburban subsample, even slightly negative). These results serve to emphasize that our evidence continues to point to the importance of the spatial distribution of jobs - albeit with a racial dimension - for
} 


\section{Quantifying the Importance of Spatial Mismatch}

We first presented evidence from a new approach to testing for spatial mismatch, based on job density, and found evidence consistent with the predictions of the model, suggesting that black employment probabilities are lower where job density in one's residential area is lower, and that this relationship is stronger at lower educational levels (both for defining job density, and the individual's level of education). We then showed, however, that it is the race-specific job densities that matter. Job density for blacks has a strong effect on black employment probabilities, while job density for whites does not. What does this evidence imply? At the risk of employing a double negative, it does not imply that space does not matter. Blacks living in areas of higher black job density do have higher employment probabilities. But the impact of space has a strong racial dimension, as higher job density for non-blacks has weak effects on black employment probabilities.

Thus, the evidence does not reject spatial mismatch per se, but it rejects what we have termed "pure spatial mismatch" - that is, that the spatial distribution of jobs, per se, is an important determinant of black employment, and in particular that a significant portion of the lower employment of blacks living in central city areas is attributable to the simple lack of nearby jobs. One way to try to make this conclusion more concrete is to ask what the estimates imply for the importance of pure spatial mismatch for black employment. In order to gauge the impact of space, per se, on black employment, we use the coefficients that we estimate in our employment model, but calculate the employment probability that would be implied if a black man lived where the representative non-black or white lived. We do this calculation for black and white males, restricting attention to high school dropouts, for whom spatial mismatch (whether race-specific or not) is most important. Table 8 lays out the steps of this calculation. ${ }^{28}$

In Panel A, we report the mean employment rates by race for male high school dropouts. For this group, the mean employment rate for blacks is 0.459 , compared with 0.690 for whites, a gap of 0.231 .

low-skilled jobs and low-skilled workers.

${ }^{28}$ This simulation obviously ignores any general equilibrium effects of many people moving, and is therefore best thought of as calculating the change in predicted employment if a small number of black males moved to areas in which they faced the job densities of the representative white male in their MSA. 
Next we report estimates from the simplest model with race-specific job densities. The model is equivalent to that in the last column of the top panel of Table 6, but using the sample of black male high school dropouts only. As reported in Panel B, the estimates reflect the same finding as before; the estimated effect of black job density is more than 10 times that of white job density. Panel C reports the means of the job density measures for blacks. There are considerably more white male jobs per black resident than black male jobs per black resident, averaged across blacks; note that the numbers are not the same as in Panel C of Table 3 because now the sample is restricted to high school dropouts. In Panel D, we instead compute the means of the same job density measures that blacks would face if they lived where the representative white in their MSA lived. ${ }^{29}$ Comparing Panels C and D, it is clear that whites on average live in areas where there are more jobs per black resident, whether held by whites or by blacks, although the difference is far greater for jobs held by whites.

Finally, we predict employment probabilities using the estimated employment model from which the coefficients in Panel B come, but substituting the job density measures in Panel D for those in Panel C (the latter are the means for blacks, which along with the means of the other variables and their coefficients yield the mean employment rate for blacks). Because both job density estimates in Panel D are higher, this obviously results in a higher predicted employment rate for blacks. Although the difference in job densities is for larger for white jobs than black jobs, because the effect of white job density on black employment is so small, this difference does not have a large effect on the predicted probability of employment. Overall, the new predicted black probability is only higher than the actual mean by 0.033 , which is a small share (14.5 percent) of the race difference in employment rates for these groups. If we do this calculation for the broader low-skill group with at most a high school education, the race difference in employment rates is 0.222 , of which space accounts for 0.032 , or 14.3 percent, a very similar conclusion. We interpret these results as indicating that space, per se, has relatively little to do

\footnotetext{
${ }^{29}$ We calculate this by computing the average job densities (on a per black resident basis) for white male high school dropouts. We then take the mean across the whites in the MSA, and assign these to each black based on their MSA of residence, and then average across blacks.
} 
with lower black employment among those with less education. ${ }^{30,31}$

There is one study that reaches a conclusion broadly consistent with our evidence that the importance of pure spatial mismatch is badly overstated. Stoll (1999) compares black-white employment gaps between Washington, DC, and two nearby suburban areas - Prince Georges and Montgomery Counties (both in Maryland). In regressions with controls for individual and family characteristics, he finds that there is no black-white employment gap in Washington, but that black employment is lower by 16-18 percentage points in the two counties, ${ }^{32}$ which he interprets as evidence that "greater employment discrimination against blacks in the suburbs could limit the potential employment gains they could enjoy by having a suburban residential location” (p. 91). However, we have doubts about evidence from comparisons between broad urban and suburban areas with no information on job density as opposed to detailed information on the availability of jobs, and we have questions about whether Stoll's conclusion follows from his findings. ${ }^{33}$

\section{$\underline{\text { VI. Conclusions }}$}

The spatial mismatch hypothesis implies that the location of jobs affects employment prospects. According to this hypothesis, the location of jobs coupled with residential segregation and mobility barriers and costs combine to reduce black employment rates, especially among those with lower skills. In

\footnotetext{
${ }^{30}$ The conclusions are very similar when using the densities computed for black and non-black men.

${ }^{31}$ It is tempting to think about some kind of decomposition that would assess the effects of pure spatial mismatch versus the effects of different effects by race. However, it is not obvious how one would calculate the effect of differential treatment by race, as doing so requires some means of predicting black (and white) employment rates absent this differential treatment. In the literature on wage equation decompositions, this is done by making an assumption about what the wage structure would look like if there were no discrimination (Neumark, 1988). Here, though, we have explicitly recognized that discrimination is not the only reason blacks and whites may be treated differently, as networks may also matter, and it is even less obvious what coefficients of an employment equation might capture the absence of network or discrimination effects.

${ }^{32}$ He studies males aged 16-21 living at home.

${ }^{33}$ In particular, Stoll hypothesizes that higher discrimination against blacks in the suburbs is attributable to "greater consumer discrimination by whites ... or to the locational self-selection of discriminating employers to the suburbs" (p. 80). But in terms of the percent black among residents, Prince Georges County (51 percent black) is much more similar to Washington (68 percent) than to Montgomery County (12 percent), so blacks should face the most discrimination in the latter. Yet the black-white employment gap - which Stoll interprets as evidence of discrimination - is no larger in Montgomery County than in Prince Georges County (his Table 7); indeed the point estimates are larger for the latter. The implication is that if one did the comparison between these two counties - for which the percentage black contrasts much more sharply than between Washington and Prince George's County one would conclude that there is no evidence of more discrimination against blacks in areas where fewer blacks live.
} 
this paper we contrast the spatial mismatch hypothesis with what we term the racial mismatch hypothesis. The latter hypothesis suggests that the problem is not a lack of jobs, per se, where blacks live, but a lack of jobs into which blacks are hired, whether because of discrimination or labor market networks in which race matters. Under the racial mismatch hypothesis, it is the local availability of jobs for (or held by) members of one's own race that matters for employment.

We begin by reporting evidence on the spatial mismatch hypothesis. We take advantage of access to all Census Long-Form respondents to assemble new evidence on spatial mismatch based on locationspecific measures of the distribution of jobs. Looking at the relationship between employment, job density, and skill, we find evidence consistent with the spatial distribution of employment opportunities coupled with residential segregation combining to reduce employment prospects for blacks. Specifically, when we construct direct measures of the presence of jobs in detailed geographic areas, we find that these job “density” measures are related to black employment in ways that would be predicted if the spatial distribution of jobs matters; in particular, black employment is higher in areas with more jobs per resident. Moreover, we construct job density measures by education level, and consider how these interact with individuals' own education level to determine employment. We find evidence consistent with spatial mismatch affecting primarily low-skilled workers, as the density of jobs for those with less than a high school degree is the most important determinant of employment, especially for blacks, and particularly for low-skilled blacks.

We then move beyond considering pure spatial mismatch to look at racial mismatch as well, by estimating the effects of job density measures that are disaggregated by race, estimating what might be viewed as “own-race” and “cross-race” job density effects on black employment. The findings, in our view, are quite striking. It is primarily black job density that influences black employment, whereas white job density has little if any influence on the employment of blacks. Moreover, we find similar patterns with respect to differences in effects associated with schooling; black job density at lower education levels has a stronger effect on employment of blacks, and in particular for those blacks with less education. 
This evidence does not repudiate the importance of the spatial distribution of jobs, given that we are still studying the effects of job density in one's area of residence. What it suggests, however, is that race plays a key role, and that the availability of jobs locally is not enough to markedly impact black employment rates. Thus, pure spatial mismatch is not an important component of lower black employment rates; instead the spatial distribution of jobs available to blacks appears to be much more important. We have termed this "racial mismatch," for short, to contrast it with the usual spatial mismatch story, and to emphasize the critical influence of race.

The evidence of racial mismatch has potentially significant implications for policies designed to counter what has been interpreted as pure spatial mismatch. Specifically, concerns over spatial mismatch have helped motivate policy interventions such as “Moving to Opportunity” (Katz, et al., 2001), "Wheels to Work” and other programs to increase access of low-income workers to cars (Goldberg, 2001), and enterprise zones (Peters and Fisher, 2002; Elvery, 2004; Busso and Kline, 2006). Interestingly, many evaluations of these programs suggest that they are relatively ineffective at increasing black employment. This is entirely consistent with the results we find here, where simply living near jobs will not boost employment unless those jobs are available to one's own race. Indeed, a simple simulation that we present shows that moving blacks so that they faced the race-specific densities of the representative white in their MSA (with the same skill level) would do relatively little to increase black employment, because the main effect of such a move would be to expose them to higher white (or non-black) job density, which our estimates indicate does little to increase black employment.

Our results demonstrate clearly that formal descriptions and empirical tests of the process by which the spatial distribution of jobs matters for black employment must take seriously the modeling of the mechanism(s) by which race matters. We previously mentioned two obvious mechanisms for which there is already some empirical support - discrimination and labor market networks - but there may be others as well. It remains an important task for future research to try to disentangle the separate impacts of these mechanisms in explaining why the existence of jobs for whites or non-blacks in a local area has little effect on black employment rates. A better understanding of these factors can facilitate the choices 
among and the design of policies to increase black employment, especially among the less skilled. 


\section{References}

Aaronson, Daniel. 1998. "Using Sibling Data to Estimate the Impact of Neighborhoods on Children's Educational Outcomes.” Journal of Human Resources, Vol. 33, No. 4, Fall, pp. 915-56.

Bayard, Kimberly, Judith Hellerstein, David Neumark, and Kenneth Troske. 1999. "Why Are Racial and Ethnic Wage Gaps Larger for Men than for Women? Exploring the Role of Segregation Using the New Worker-Establishment Characteristics Database.” In The Creation and Analysis of Employer-Employee Matched Data, eds. Haltiwanger, Lane, Spletzer, Theeuwes, and Troske (Amsterdam: Elsevier Science B.V.), pp. 175-203.

Bayer, Patrick, Stephen Ross, and Giorgio Topa. 2005. "Place of Work and Place of Residence: Informal Hiring Networks and Labor Market Outcomes.” NBER Working Paper No. 11019.

Becker, Gary S. 1971. The Economics of Discrimination, Second Edition (Chicago: University of Chicago Press).

Bergmann, Barbara. 1974. “Occupational Segregation, Wages and Profits when Employers Discrimination by Race or Sex.” Eastern Economic Journal, Vol. 1, Nos. 1-2, pp. 103-10.

Bertrand, Marianne, and Sendhil Mullainathan. 2004. "Are Emily and Greg More Employable Than Lakisha and Jamal? A Field Experiment on Labor Market Discrimination.” American Economic Review, Vol. 94, No. 4, pp. 991-1013.

Borjas, George. 1995. "Ethnicity, Neighborhood, and Human Capital Externalities.” American Economic Review, Vol. 85, No. 3, June, pp. 365-90.

Busso, Matias, and Patrick Kline. 2006. "Do Local Economic Development Programs Work? Evidence from the Federal Empowerment Zone Program.” Unpublished paper, University of Michigan.

Case, Anne C., and Lawrence F. Katz. 1991. "The Company You Keep: The Effects of Family and Neighborhood on Disadvantaged Youth.” NBER Working Paper No. 3705.

Cooke, Thomas J. 1996. "City-Suburb Differences in African American Male Labor Market Achievement.” Professional Geographer, Vol. 48, No. 4, pp. 458-67.

Cutler, David M., Edward L. Glaeser, and Jacob L. Vigdor. 1997. "The Rise and Decline of the American Ghetto.” NBER Working Paper No. 5881.

Cutler, David M., and Edward L. Glaeser. 1997. “Are Ghettos Good or Bad?” Quarterly Journal of Economics, Vol. 112, No. 3, August, pp. 827-72.

Ellwood, David. 1986. “The Spatial Mismatch Hypothesis: Are There Jobs Missing in the Ghetto?” In The Black Youth Employment Crisis, eds. Freeman and Holzer (Chicago: University of Chicago Press), pp. 147-85.

Elvery, Joel. 2004. "Evaluating the Effects of Enterprise Zones on Resident Employment: Do Resident Characteristics Matter?” BLS Working Paper.

Evans, William N., Wallace E. Oates, and Robert M. Schwab. 1992. "Measuring Peer Group Effects: A Study of Teenage Behavior.” Journal of Political Economy, Vol. 100, No. 5, October, pp. 966-91. 
Goldberg, Heidi. 2001. "State and County Supported Car Ownership Programs Can Help Low-Income Families Secure and Keep Jobs.” Center on Budget and Policy Priorities, November 28, available at http://www.cbpp.org/11-8-01wel.htm (as of October 28, 2005).

Granovetter, Mark S. 1974. Getting a Job: A Study of Contacts and Careers (Cambridge, MA: Harvard University Press).

Harrison, Bennett. 1972. “The Intrametropolitan Distribution of Minority Economic Welfare.” Journal of Regional Science, Vol. 12, pp. 23-43.

Holzer, Harry J. 1991. “The Spatial Mismatch Hypothesis: What Has the Evidence Shown?” Urban Studies, Vol. 28, No. 1, pp. 105-22.

Hughes, Mark A., and Janice Madden. 1991. "Residential Segregation and the Economic Status of Black Workers: New Evidence for an Old Debate.” Journal of Urban Economics, Vol. 29, No. 1, January, pp. 28-49.

Hutchinson, Peter. 1974. "The Effects of Accessibility and Segregation on the Employment of the Urban Poor.” In Patterns of Racial Discrimination, Volume 1, eds. von Furstenburg, Harrison, and Horowitz (Lexington, MA: Lexington Books), pp. 77-96.

Ihlandfeldt, Keith R. 1992. Job Accessibility and the Employment and School Enrollment of Teenagers (Kalamazoo, MI: W. E. Upjohn Institute for Employment Research).

Ihlanfeldt, Keith R., and David Sjoquist. 1990. “Job Accessibility and Racial Differences in Youth Employment Rates.” American Economic Review, Vol. 80, No. 1, March, pp. 267-76.

Ihlanfeldt, Keith R., and David Sjoquist. 1998. "The Spatial Mismatch Hypothesis: A Review of Recent Studies and Their Implications for Welfare Reform.” Housing Policy Debate, Vol. 8, No. 4, pp. 849-92.

Jencks, Christopher, and Susan E. Mayer. 1990. "Residential Segregation, Job Proximity, and Black Job Opportunities.” In Inner-City Poverty in the United States, eds. Lynn and McGreary (Washington, DC: National Academy Press), pp. 187-222.

Kain, John. 1968. “Housing Segregation, Negro Employment, and Metropolitan Decentralization.” Quarterly Journal of Economics, Vol. 82, No. 2, May, pp. 175-97.

Kasarda, John D. 1989. "Urban Industrial Transition and the Underclass.” The Annals of the American Academy of Political and Social Science, Vol. 501, pp. 26-47.

Kasarda, John D., and Kwok-fai Ting. 1996. “Joblessness and Poverty in America’s Central Cities: Causes and Policy Prescriptions.” Housing Policy Debate, Vol. 7, No. 2, p. 387-419.

Katz, Lawrence F., Jeffrey R. Kling, and Jeffrey B. Liebman. 2001. "Moving to Opportunity in Boston: Early Results of a Randomized Mobility Experiment.” Quarterly Journal of Economics, Vol. 116, No. 2, May, pp. 607-54.

Massey, Douglas, and Nancy Denton. 1987. "Trends in the Residential Segregation of Blacks, Hispanics, and Asians: 1970-1980.” American Sociological Review, Vol. 52, No. 6, December, pp. 802-25.

Masters, Stanley H. 1974. “A Note on John Kain’s “Housing Segregation, Negro Employment, and Metropolitan Decentralization”.” Quarterly Journal of Economics, Vol. 88, No. 3, August, pp. 505-12. 
Masters, Stanley H. 1975. Black-White Income Differentials: Empirical Studies and Policy Implications (New York: Academic Press).

Neumark, David. 1988. “Employers' Discriminatory Behavior and the Estimation of Wage Discrimination.” Journal of Human Resources, Vol. 23, No. 3, Summer, pp. 279-95.

Offner, Paul, and Daniel H. Saks. 1971. “A Note on John Kain’s "Housing Segregation, Negro Employment, and Metropolitan Decentralization”.” Quarterly Journal of Economics, Vol. 85, No. 1, February, pp. 147-60.

O’Regan, Katherine M., and John M. Quigley. 1996. "Where Youth Live: Economic Effects of Urban Space on Employment Prospects.” Urban Studies, Vol. 35, No. 7, June, pp. 1187-1205.

Peters, Alan H., and Peter S. Fisher. 2002. State Enterprise Zone Programs: Have They Worked? (Kalamazoo, MI: W. E. Upjohn Institute for Employment Research).

Price, Richard, and Edwin Mills. 1985. "Race and Residence in Earnings Determination.” Journal of Urban Economics, Vol. 17, No. 1, January, pp. 1-18.

Raphael, Steven. 1998. "The Spatial Mismatch Hypothesis of Black Youth Joblessness: Evidence from the San Francisco Bay Area.” Journal of Urban Economics, Vol. 43, No. 1, January, pp. 79-111.

Stoll, Michael A. 1999. "Spatial Mismatch, Discrimination, and Male Youth Employment in the Washington, DC Area: Implications for Residential Mobility Policies.” Journal of Policy Analysis and Management, Vol. 18, No. 1, Winter, pp. 77-98.

Turner, Margery A., Michael Fix, and Raymond J. Struyk. 1991. Opportunities Denied, Opportunities Diminished: Racial Discrimination in Hiring (Washington, DC: Urban Institute Press).

Vrooman, John, and Stuart Greenfield. 1980. "Are Blacks Making It in the Suburbs? Some New Evidence on Intrametropolitan Spatial Segmentation.” Journal of Urban Economics, Vol. 7, No. 2, March, pp. 15567.

Weinberg, Bruce. 2002. “Testing the Spatial Mismatch Hypothesis Using Inter-City Variations in Industrial Composition.” Unpublished paper, Ohio State University.

Wilson, William Julius. 1987. The Truly Disadvantaged (Chicago: University of Chicago Press).

Zax, Jeffrey, and John F. Kain. 1998. "Moving to the Suburbs: Do Relocating Companies Leave Their Black Employees Behind?” Journal of Labor Economics, Vol. 14, No. 3, July, pp. 472-504. 
Full SEDF (not institutionalized)

Restrict to men

Exclusion criteria (total cases):

Not in CMSA/MSA

Not in age range 16-64

In military

Enrolled in school

Work limiting disability

SEDF observations retained

Live in water zip

Work in water zip

Observations with unmatched or allocated place of work location

Total observations remaining for calculation of densities

Observations dropped because of missing densities, insufficient population size

\section{Final sample}

Percentage employed in own zip code (if employed)

Percentage employed in contiguous zip code area (if employed)

Percentage employed in MSA/PMSA (if employed)
(1)

Total

42,583, 178

$20,713,501$ Black males

.. $\quad 377,562$

... 890,056

... 13,556

... $\quad 905,359$

... 259,636

700,303

2,888

2,816

158,989

535,677

$\begin{array}{ll}\cdots & 2,479\end{array}$

533,198

14

34

92

SEDF: Sample Edited Detail File of all Long-Form Census respondents. The exclusion criteria are not mutually exclusive, so many observations show up in multiple rows. 
Table 2: Comparisons of Individual Characteristics and Overall Job Density Measures by Race

(1) (2)

(3)

(4)

A. Individual characteristics (means):

Black men Non-black men White men

Employment

.67

.84

.86

Individual characteristics:

Central city

LTHS

$\begin{array}{lll}.58 & .30 \quad .27\end{array}$

HSD

.24

.16

.10

.34

.27

.28

SCOL

.42

.57

.62

B. Overall job density measures:

Mean (SD) $\quad 25^{\text {th }} \%$-ile $\quad$ Median $\quad 75^{\text {th }} \%$-ile

Jobs/residents

Blacks

$.77(.58)$

.48

.66

.91

Whites

$.73(.45)$

.51

.66

.86

Male jobs/male resident

Blacks

Whites

Black and white male jobs/black and white male residents

\begin{tabular}{c} 
Blacks \\
Whites \\
\hline C. Overall job density measures (High school or less)
\end{tabular}

C. Overall job density measures (High school or less)

$.80(.50)$

$$
.54
$$

.75

1.05

$91(72)$

$.91(.72)$

$.81(.54)$

Mean (SD)

.54

.72

.95

Jobs/residents

Blacks

Whites

$.66(.50)$

$.74(.59)$

.75 (.53)

$.83(.65)$

Blacks

Male jobs/male resident

Black and white male jobs/black and white male residents

Blacks
Whites

D. Overall job density measures (Less than high school)

Jobs/residents

Blacks

$.78(.59)$

$.84(.67)$

Mean (SD)

.56

$\begin{array}{ll}.56 & .78 \\ .54 & .73\end{array}$

1.08

.97

$25 \%$-ile $\quad$ Median $75 \%$-ile

$25 \%$-ile

78

$.49 \quad .65$

.86

65

.58

.67

.89

.74

.98

.55

.49

.68

.94

.74

1.00

.55

$25 \%$-ile

Median

$75 \%$-ile
Blacks
Whites

$.50(.39)$
$.66(.56)$

$.61(.45)$

.78 (.66)

Whites

Black and white male jobs/black and white male residents

Blacks

Whites
$.62(.46)$

$.75(.58)$

$$
.31
$$$$
.43
$$$$
.39
$$

.38

.50
.45

.57

.55

.67

.54

.66

.66

.75

.89

There are 533,198 observations on black men, and 4,030,425 on white men, using the sample construction rules in Table 1. Standard deviations (SD) of continuous variables are reported in parentheses in column (1) of Panels B through D. All estimates are weighted to account for differences in the probability of having valid place of work data. To comply with disclosure restrictions, "pseudo-quartiles" are reported. "LTHS" refers to those without a high school diploma, "HSD" represents high school graduates, and "SCOL" refers to those with at least some college education, including college graduates. 
Table 3: Race-Specific Job Density Measures for Black Men

\begin{tabular}{|c|c|c|c|c|}
\hline & $(1)$ & $(2)$ & $(3)$ & $(4)$ \\
\hline & Mean (SD) & $25^{\text {th }} \%$-ile & Median & $75^{\text {th }} \%$-ile \\
\hline \multicolumn{5}{|l|}{ A. Overall } \\
\hline Non-black jobs/black residents & $6.11(15.65)$ & .99 & 2.28 & 5.49 \\
\hline $\begin{array}{l}\text { Non-black male jobs/black male } \\
\text { residents }\end{array}$ & $6.92(16.12)$ & 1.29 & 2.85 & 6.73 \\
\hline White male jobs/black male residents & $5.75(14.11)$ & 1.03 & 2.41 & 5.62 \\
\hline Black jobs/black residents & $.61(.73)$ & .32 & .47 & .68 \\
\hline Black male jobs/black male residents & $.62(.70)$ & .33 & .49 & .72 \\
\hline \multicolumn{5}{|l|}{ B. $L T H S+H S D$} \\
\hline Non-black jobs/black residents & $3.94(12.01)$ & .56 & 1.30 & 3.37 \\
\hline $\begin{array}{l}\text { Non-black male jobs/black male } \\
\text { residents }\end{array}$ & $5.59(16.30)$ & .80 & 1.86 & 4.82 \\
\hline White male jobs/black male residents & 4.05 (13.19) & .56 & 1.41 & 3.55 \\
\hline Black jobs/black residents & $.58(.76)$ & .30 & .45 & .65 \\
\hline Black male jobs/black male residents & $.58(.89)$ & .28 & .43 & .65 \\
\hline \multicolumn{5}{|l|}{ C. LTHS } \\
\hline Non-black jobs/black residents & $4.30(14.49)$ & .44 & 1.07 & 3.14 \\
\hline $\begin{array}{l}\text { Non-black male jobs/black male } \\
\text { residents }\end{array}$ & $5.54(18.25)$ & .60 & 1.51 & 4.24 \\
\hline White male jobs/black male residents & $2.73(9.14)$ & .33 & .83 & 2.31 \\
\hline Black jobs/black residents & $.46(.85)$ & .21 & .33 & .49 \\
\hline Black male jobs/black male residents & $.51(.86)$ & .23 & .36 & .54 \\
\hline
\end{tabular}

There are 533,198 observations. Standard deviations (SD) of continuous variables are reported in parentheses in column (1). All estimates are weighted to account for differences in the probability of having valid place of work data. To comply with disclosure restrictions, "pseudo-quartiles" are reported. 


\section{Central city}

Central city $x$

$-0.059$

(0.003)

own educ. LTHS

Central city $\times$

own educ. HSD

Central city $\times$

own educ. SCOL

$\mathrm{R}^{2}$

.131

There are 533,198 observations on blacks. Regression estimates are from linear probability models, with standard errors in parentheses. All specifications include controls for age (linear and quadratic terms), marital status (a dummy variable for currently married), highest education (six categories including less than high school, high school degree, some college, Associate's degree, Bachelor's degree, and advanced degree), and Census region (South, West, Northeast, and North Central). There is also a control for other city (non-central), and the omitted category is suburb (the rest of the CMSA/MSA). All estimates are weighted to account for differences in the probability of having valid place of work data. All standard errors account for non-independence of observations within zip code areas, and allow for heteroscedasticity across zip code areas. 
Table 5: Employment Regressions for Black Men, Alternative Aggregate Density Measures, With and Without Own Education Interactions, Contiguous Zip Codes

\begin{tabular}{|c|c|c|c|c|c|c|c|c|c|}
\hline & (1) & $(2)$ & (3) & (4) & (5) & (6) & $(7)$ & $(8)$ & (9) \\
\hline $\begin{array}{l}\text { Job density } \\
\text { measure: }\end{array}$ & & Jobs/resident & & & jobs/male resi & & \multicolumn{3}{|c|}{$\begin{array}{c}\text { Black or white male jobs/ } \\
\text { black or white male resident }\end{array}$} \\
\hline $\begin{array}{l}\text { Job density } \\
\text { defined for: }\end{array}$ & All & LTHS+HSD & LTHS & All & LTHS+HSD & LTHS & All & LTHS+HSD & LTHS \\
\hline Job density & $\begin{array}{l}.009 \\
(.003)\end{array}$ & $\begin{array}{l}.037 \\
(.004)\end{array}$ & $\begin{array}{l}.073 \\
(.009)\end{array}$ & $\begin{array}{c}.005 \\
(.003)\end{array}$ & $\begin{array}{l}.037 \\
(.003)\end{array}$ & $\begin{array}{l}.058 \\
(.006)\end{array}$ & $\begin{array}{c}.001 \\
(.002)\end{array}$ & $\begin{array}{c}.032 \\
(.003)\end{array}$ & $\begin{array}{c}.066 \\
(.005)\end{array}$ \\
\hline $\mathrm{R}^{2}$ & .131 & 0.132 & .134 & .131 & .132 & .134 & .131 & .132 & .134 \\
\hline $\begin{array}{l}\text { Jobs/resident } \\
\times \text { own education } \\
\text { LTHS }\end{array}$ & $\begin{array}{l}-.003 \\
(.005)\end{array}$ & $\begin{array}{l}.038 \\
(.007)\end{array}$ & $\begin{array}{l}.128 \\
(.014)\end{array}$ & $\begin{array}{l}-.007 \\
(.004)\end{array}$ & $\begin{array}{l}.044 \\
(.006)\end{array}$ & $\begin{array}{c}.099 \\
(.010)\end{array}$ & $\begin{array}{l}-.010 \\
(.004)\end{array}$ & $\begin{array}{l}.036 \\
(.005)\end{array}$ & $\begin{array}{l}.101 \\
(.008)\end{array}$ \\
\hline $\begin{array}{l}\text { Jobs/resident } \\
\times \text { own education } \\
\text { HSD }\end{array}$ & $\begin{array}{l}.007 \\
(.004)\end{array}$ & $\begin{array}{c}.049 \\
(.006)\end{array}$ & $\begin{array}{l}.123 \\
(.012)\end{array}$ & $\begin{array}{c}.002 \\
(.004)\end{array}$ & $\begin{array}{l}.051 \\
(.005)\end{array}$ & $\begin{array}{l}.095 \\
(.008)\end{array}$ & $\begin{array}{l}-.003 \\
(.004)\end{array}$ & $\begin{array}{l}.041 \\
(.005)\end{array}$ & $\begin{array}{c}.097 \\
(.006)\end{array}$ \\
\hline $\begin{array}{l}\text { Jobs/resident } \\
\times \text { own education } \\
\text { SCOL }\end{array}$ & $\begin{array}{l}.020 \\
(.003)\end{array}$ & $\begin{array}{c}.031 \\
(.003)\end{array}$ & $\begin{array}{c}.041 \\
(.006)\end{array}$ & $\begin{array}{c}.015 \\
(.002)\end{array}$ & $\begin{array}{l}.028 \\
(.003)\end{array}$ & $\begin{array}{c}.033 \\
(.004)\end{array}$ & $\begin{array}{c}.011 \\
(.002)\end{array}$ & $\begin{array}{l}.026 \\
(.002)\end{array}$ & $\begin{array}{l}.040 \\
(.003)\end{array}$ \\
\hline $\mathrm{R}^{2}$ & .131 & .132 & .135 & .131 & .133 & .134 & .131 & .132 & .135 \\
\hline
\end{tabular}

There are 533,198 observations. See notes to Table 4. 
Table 6: Employment Regressions for Black Men, Alternative Race-Specific Density Measures, With and Without Own Education Interactions,

Contiguous Zip Codes

\begin{tabular}{|c|c|c|c|c|c|c|c|c|c|}
\hline & $(1)$ & $(2)$ & (3) & $(4)$ & $(5)$ & $(6)$ & $(7)$ & $(8)$ & $(9)$ \\
\hline $\begin{array}{l}\text { Job density } \\
\text { measure: }\end{array}$ & \multicolumn{3}{|c|}{$\begin{array}{c}\text { Non-black jobs or black jobs/ } \\
\text { black resident }\end{array}$} & \multicolumn{3}{|c|}{$\begin{array}{c}\text { Male non-black jobs or male black jobs/ } \\
\text { black male resident }\end{array}$} & \multicolumn{3}{|c|}{$\begin{array}{c}\text { Male white jobs or male black jobs/ } \\
\text { black male resident }\end{array}$} \\
\hline defined for: & All & LTHS+HSD & LTHS & All & LTHS+HSD & LTHS & All & LTHS+HSD & LTHS \\
\hline $\begin{array}{l}\text { Non-black or white } \\
\text { job density }\end{array}$ & $\begin{array}{c}.001 \\
(.0001)\end{array}$ & $\begin{array}{c}.001 \\
(.0001)\end{array}$ & $\begin{array}{c}.001 \\
(.0001)\end{array}$ & $\begin{array}{c}.001 \\
(.0001)\end{array}$ & $\begin{array}{c}.001 \\
(.0001)\end{array}$ & $\begin{array}{c}.001 \\
(.0001)\end{array}$ & $\begin{array}{c}.001 \\
(.0001)\end{array}$ & $\begin{array}{c}.001 \\
(.0001)\end{array}$ & $\begin{array}{c}.002 \\
(.0001)\end{array}$ \\
\hline Black job density & $\begin{array}{c}.009 \\
(.002)\end{array}$ & $\begin{array}{c}.016 \\
(.002)\end{array}$ & $\begin{array}{c}.017 \\
(.003)\end{array}$ & $\begin{array}{c}.009 \\
(.002)\end{array}$ & $\begin{array}{c}.014 \\
(.003)\end{array}$ & $\begin{array}{l}.019 \\
(.002)\end{array}$ & $\begin{array}{c}.010 \\
(.002)\end{array}$ & $\begin{array}{c}.015 \\
(.002)\end{array}$ & $\begin{array}{c}.017 \\
(.002)\end{array}$ \\
\hline $\mathrm{R}^{2}$ & .133 & .133 & .133 & .133 & .133 & .133 & .133 & .133 & .133 \\
\hline $\begin{array}{l}\text { Non-black jobs/ } \\
\text { black resident } \\
\times \text { own educ. LTHS }\end{array}$ & $\begin{array}{c}.002 \\
(.0002)\end{array}$ & $\begin{array}{c}.002 \\
(.0002)\end{array}$ & $\begin{array}{c}.001 \\
(.0003)\end{array}$ & $\begin{array}{c}.002 \\
(.0003)\end{array}$ & $\begin{array}{c}.001 \\
(.0002)\end{array}$ & $\begin{array}{c}.001 \\
(.0002)\end{array}$ & $\begin{array}{c}.002 \\
(.0003)\end{array}$ & $\begin{array}{c}.002 \\
(.0003)\end{array}$ & $\begin{array}{c}.003 \\
(.0003)\end{array}$ \\
\hline $\begin{array}{l}\text { Black jobs/ } \\
\text { black resident } \\
\times \text { own educ. LTHS }\end{array}$ & $\begin{array}{c}.009 \\
(.005)\end{array}$ & $\begin{array}{c}.024 \\
(.005)\end{array}$ & $\begin{array}{c}.046 \\
(.008)\end{array}$ & $\begin{array}{c}.009 \\
(.005)\end{array}$ & $\begin{array}{c}.030 \\
(.006)\end{array}$ & $\begin{array}{c}.047 \\
(.006)\end{array}$ & $\begin{array}{c}.009 \\
(.005)\end{array}$ & $\begin{array}{c}.030 \\
(.006)\end{array}$ & $\begin{array}{c}.040 \\
(.006)\end{array}$ \\
\hline $\begin{array}{l}\text { Non-black jobs/ } \\
\text { black resident } \\
\times \text { own educ. HSD }\end{array}$ & $\begin{array}{c}.002 \\
(.0001)\end{array}$ & $\begin{array}{c}.002 \\
(.0002)\end{array}$ & $\begin{array}{c}.001 \\
(.0002)\end{array}$ & $\begin{array}{c}.002 \\
(.0001)\end{array}$ & $\begin{array}{c}.001 \\
(.0001)\end{array}$ & $\begin{array}{c}.001 \\
(.0001)\end{array}$ & $\begin{array}{c}.002 \\
(.0002)\end{array}$ & $\begin{array}{c}.002 \\
(.0002)\end{array}$ & $\begin{array}{c}.002 \\
(.0002)\end{array}$ \\
\hline $\begin{array}{l}\text { Black jobs/ } \\
\text { black resident } \\
\times \text { own educ. HSD }\end{array}$ & $\begin{array}{c}.013 \\
(.004)\end{array}$ & $\begin{array}{c}.025 \\
(.004)\end{array}$ & $\begin{array}{c}.031 \\
(.007)\end{array}$ & $\begin{array}{c}.012 \\
(.004)\end{array}$ & $\begin{array}{c}.026 \\
(.004)\end{array}$ & $\begin{array}{c}.034 \\
(.004)\end{array}$ & $\begin{array}{c}.013 \\
(.004)\end{array}$ & $\begin{array}{c}.027 \\
(.004)\end{array}$ & $\begin{array}{c}.030 \\
(.004)\end{array}$ \\
\hline $\begin{array}{l}\text { Non-black jobs/ } \\
\text { black resident } \\
\times \text { own educ. SCOL }\end{array}$ & $\begin{array}{c}.001 \\
(.0001)\end{array}$ & $\begin{array}{c}.001 \\
(.0001)\end{array}$ & $\begin{array}{c}.001 \\
(.0001)\end{array}$ & $\begin{array}{c}.001 \\
(.0001)\end{array}$ & $\begin{array}{c}.001 \\
(.0001)\end{array}$ & $\begin{array}{c}.0005 \\
(.0001)\end{array}$ & $\begin{array}{c}.001 \\
(.0001)\end{array}$ & $\begin{array}{c}.001 \\
(.0001)\end{array}$ & $\begin{array}{c}.001 \\
(.0001)\end{array}$ \\
\hline $\begin{array}{l}\text { Black jobs/ } \\
\text { black resident } \\
\times \text { own educ. SCOL }\end{array}$ & $\begin{array}{c}.008 \\
(.002)\end{array}$ & $\begin{array}{c}.011 \\
(.002)\end{array}$ & $\begin{array}{c}.007 \\
(.002)\end{array}$ & $\begin{array}{c}.008 \\
(.002)\end{array}$ & $\begin{array}{c}.007 \\
(.002)\end{array}$ & $\begin{array}{c}.009 \\
(.001)\end{array}$ & $\begin{array}{c}.009 \\
(.002)\end{array}$ & $\begin{array}{c}.008 \\
(.002)\end{array}$ & $\begin{array}{c}.009 \\
(.001)\end{array}$ \\
\hline $\mathrm{R}^{2}$ & .133 & .133 & .134 & .133 & .134 & .134 & .134 & 0.134 & .134 \\
\hline
\end{tabular}

There are 533,198 observations. See notes to Tables 4 and 5. 
Table 7: Employment Regressions for Black Men, With and Without Own Education Interactions, Contiguous Zip Codes, Robustness Analyses

\begin{tabular}{|c|c|c|c|c|c|c|c|}
\hline & (1) & (2) & (3) & (4) & (5) & (6) & (7) \\
\hline Analysis/restriction & $\begin{array}{l}\text { Baseline, } \\
\text { Table 6, } \\
\text { Column (9) }\end{array}$ & $\begin{array}{c}\text { Cells with At Least } \\
10 \text { Black Men for } \\
\text { Computing Density } \\
\text { Measure }\end{array}$ & $\begin{array}{l}\text { Excluding } \\
\text { Suburban } \\
\text { Residents }\end{array}$ & $\begin{array}{l}\text { Including } \\
\text { State Fixed } \\
\text { Effects }\end{array}$ & $\begin{array}{l}\text { Including } \\
\text { MSA Fixed } \\
\text { Effects }\end{array}$ & $\begin{array}{c}\text { Individuals } \\
\text { Who Moved } \\
\text { within Last } 5 \\
\text { Years }\end{array}$ & $\begin{array}{l}\text { Individuals } \\
\text { Who Did Not } \\
\text { Move within } \\
\text { Last } 5 \text { Years }\end{array}$ \\
\hline White male & .002 & .008 & .002 & .001 & .0005 & .001 & .002 \\
\hline job density & $(.0001)$ & $(.0005)$ & $(.0003)$ & $(.0001)$ & $(.0002)$ & $(.0001)$ & $(.0002)$ \\
\hline Black job density & .017 & .015 & .013 & .017 & .018 & .016 & .018 \\
\hline $\mathrm{R}^{2}$ & .133 & .135 & .130 & .136 & .140 & .120 & .147 \\
\hline $\begin{array}{l}\text { White male jobs/ } \\
\text { black male resident } \\
\times \text { own educ. LTHS }\end{array}$ & $\begin{array}{c}.003 \\
(.0003)\end{array}$ & $\begin{array}{l}.010 \\
(.001)\end{array}$ & $\begin{array}{c}.004 \\
(.0006)\end{array}$ & $\begin{array}{c}.002 \\
(.0003)\end{array}$ & $\begin{array}{c}.001 \\
(.0003)\end{array}$ & $\begin{array}{c}.001 \\
(.0004)\end{array}$ & $\begin{array}{l}.002 \\
(.001)\end{array}$ \\
\hline $\begin{array}{l}\text { Black male jobs/ } \\
\text { black male resident } \\
\times \text { own educ. LTHS }\end{array}$ & $\begin{array}{c}.040 \\
(.006)\end{array}$ & $\begin{array}{l}.050 \\
(.011)\end{array}$ & $\begin{array}{l}.028 \\
(.006)\end{array}$ & $\begin{array}{l}.040 \\
(.005)\end{array}$ & $\begin{array}{l}.038 \\
(.005)\end{array}$ & $\begin{array}{l}.056 \\
(.007)\end{array}$ & $\begin{array}{l}.041 \\
(.008)\end{array}$ \\
\hline $\begin{array}{l}\text { White male jobs/ } \\
\text { black male resident } \\
\times \text { own educ. HSD }\end{array}$ & $\begin{array}{c}.002 \\
(.0002)\end{array}$ & $\begin{array}{c}.010 \\
(.0007)\end{array}$ & $\begin{array}{c}.004 \\
(.001)\end{array}$ & $\begin{array}{c}.002 \\
(.0002)\end{array}$ & $\begin{array}{c}.001 \\
(.0002)\end{array}$ & $\begin{array}{c}.002 \\
(.0002)\end{array}$ & $\begin{array}{c}.002 \\
(.0004)\end{array}$ \\
\hline $\begin{array}{l}\text { Black male jobs/ } \\
\text { black male resident } \\
\times \text { own educ. HSD }\end{array}$ & $\begin{array}{l}.030 \\
(.004)\end{array}$ & $\begin{array}{c}.033 \\
(.007)\end{array}$ & $\begin{array}{l}.027 \\
(.006)\end{array}$ & $\begin{array}{l}.030 \\
(.004)\end{array}$ & $\begin{array}{l}.029 \\
(.004)\end{array}$ & $\begin{array}{l}.026 \\
(.005)\end{array}$ & $\begin{array}{c}.032 \\
(.005)\end{array}$ \\
\hline $\begin{array}{l}\text { White male jobs/ } \\
\text { black male resident } \\
\times \text { own educ. SCOL }\end{array}$ & $\begin{array}{c}.001 \\
(.0001)\end{array}$ & $\begin{array}{c}.005 \\
(.0004)\end{array}$ & $\begin{array}{c}.002 \\
(.0003)\end{array}$ & $\begin{array}{l}.0004 \\
(.0001)\end{array}$ & $\begin{array}{l}-.0001 \\
(.0001)\end{array}$ & $\begin{array}{c}.001 \\
(.0001)\end{array}$ & $\begin{array}{c}.001 \\
(.0002)\end{array}$ \\
\hline $\begin{array}{l}\text { Black male jobs/ } \\
\text { black male resident } \\
\times \text { own educ. SCOL }\end{array}$ & $\begin{array}{c}.009 \\
(.001)\end{array}$ & $\begin{array}{l}.005 \\
(.003)\end{array}$ & $\begin{array}{c}.007 \\
(.002)\end{array}$ & $\begin{array}{c}.010 \\
(.001)\end{array}$ & $\begin{array}{c}.011 \\
(.001)\end{array}$ & $\begin{array}{l}.007 \\
(.001)\end{array}$ & $\begin{array}{c}.008 \\
(.002)\end{array}$ \\
\hline $\mathrm{R}^{2}$ & .134 & .136 & .131 & .137 & .141 & .121 & .147 \\
\hline $\mathrm{N}$ & 533,198 & 513,312 & 338,128 & 533,198 & 533,198 & 264,932 & 268,266 \\
\hline
\end{tabular}

The density measures in this table are always defined in terms of male white jobs or male black jobs per black male resident, for those with less than a high school degree. See notes to Tables 4 and 5. 
Table 8: Calculation of Effects of Space on Black-White Employment Differential, Black Male High School Dropouts

\section{A. Mean employment rates}

Black male employment

White male employment

B. Regression estimates of job density coefficients

White male jobs/black male resident

Black male jobs/black male resident

C. Mean job densities for black males

White male jobs/black male resident 1.985

Black male jobs/black male resident

0.432

D. Mean job densities for representative white males in same MSA as black males

White male jobs/black male resident

7.868

Black male jobs/black male resident

0.886

E. Predicted black male employment rate if black males faced job

0.492

densities of average white male in MSA (substituting job densities from

Panel D into employment model)

Specification is the same as in top panel of Table 6, including only high school dropouts in the sample. The sample size is 129,348 . The other controls included in the regression are the same as in the regressions in the previous tables; see notes to Tables 4 and 5. 